\title{
Isparta-Atabey Yöresinin Ekoturizm Potansiyeli ve Turizm Rotalarının Belirlenmesi
}

\author{
Tuğba AKIN ${ }^{1 *}$ (๑) Atila GÜL² \\ ${ }^{1}$ Süleyman Demirel Üniversitesi, Fen Bilimleri Enstitüsü, Peyzaj Mimarlığı Ana Bilim Dalı, 32260, Isparta, Türkiye. \\ 2 Süleyman Demirel Üniversitesi, Mimarlık Fakültesi, Peyzaj Mimarlığı Bölümü, 32260, Isparta, Türkiye \\ *tugbaakin21@gmail.com
}

\section{Öz}

Turizmde miras değeri taşıyan doğal ve kültürel kaynak değerlerinin korunması, yaşatılması ve gelecek nesillere aktarılması önemlidir. Özellikle ekoturizmin giderek önem kazanması ve turizm rotaları ile ilişkilendirilmesi sonucu yörenin turizm faaliyetlerinin geliştirilmesi adına bir fırsat oluşturmaktadır. Rotalardaki temel amaç; rota üzerinde öngörülen doğal ve kültürel değerlerinin birbirleriyle entegre edilmesi, yörenin geliştirilmesi ve turistlerin keşfetme ve tatmin düzeyinin artırılmasıdır. Çalışma alanı Atabey ilıçesi olup turizm amaçlı doğal ve kültürel kaynak değerleri ve potansiyeli belirlenmiştir. Bu çalışmada ArcGIS 10.7 programı kullanılarak ağ analizi (network analysis) yöntemi kullanılarak kısa, orta ve uzun mesafeli turizm rotaları önerilmiştir. Sonuç olarak Atabey ilç̧esindeki önerilen rotalarda doğal ve kültürel kaynak değerleri için gereken eylemler önerilmiştir. Bu sonuçlar Atabey ve Isparta turizm kapasitesinin geliştirilmesinde önemli bir rehber niteliği taşıyacaktır.

Anahtar Kelimeler: Atabey, ekoturizm, turizm rotaları, CBS, Isparta

\section{The Determination of the Tourism Routes and the Ecotourism Potential of the Isparta-Atabey}

\begin{abstract}
It is important to protect natural and cultural resource values that have heritage value in tourism, to keep them alive and to pass them on to future generations. Especially as ecotourism gains importance and is associated with tourism routes, it creates an opportunity for the development of tourism activities in the region. The main purpose of the routes; integrating the natural and cultural values envisaged on the route with each other, developing the region and increasing the exploration and satisfaction level of the tourists. The study area was Atabey District and the values and potential of natural and cultural resources for tourism purposes have been determined. In this study, short, medium and long distance tourism routes were proposed by using network analysis method using ArcGIS 10.7 program. As a result, necessary actions for natural and cultural resource values were proposed in the proposed routes in Atabey District. These results will serve as an important guide for the development of tourism capacity of Atabey and Isparta.
\end{abstract}

Keywords: Atabey, ecotourism, tourism routes, GIS, Isparta

Atıf/Citation: Akın, T. ve Gül, A. (2020). Isparta-Atabey Yöresinin Ekoturizm Potansiyeli ve Turizm Rotalarının Belirlenmesi. Mimarlık Bilimleri ve Uygulamaları Dergisi, 5(2), 221-240.

DOI: $\underline{10.30785 / \mathrm{mbud} .793234}$ 


\section{Giriş}

Günümüzde nüfus artışı, dikey ve yatay yapılaşmalar, açık ve yeşil alanların nitelik ve nicelik olarak yetersizliği, çevresel kirlilik, gürültü kirliliği, yanlış arazi kullanım planlaması ve yönetim politikaları, arazi rant yaklaşımları vb. birçok etken kentleşme eğilimlerinin sağlıksız ve olumsuz bir şekilde gelişmesine yol açmıştır. Kentleşme eğilimleri sonucu kentlerin doğadan giderek uzaklaşarak suni mekânlar haline gelmesi, yaşam kalitesinin azalması gibi faktörler doğaya özlem duyulmasını, kent ortamından uzaklaşarak doğa ve kültür değerlerinin keşfedilmesini, ziyaret edilmesini ve o mekânlarda vakit geçirme isteğini ön plana çıkarmıştır. Doğal ve kültürel kaynak değerleri açısından ekoturizm, doğa tabanlı turizm, kültür turizmi, sağlık turizmi gibi birçok kavramlar ön plana çıkmıştır. Bundan dolayı da doğa tabanlı turizm ve sürdürülebilir turizm insanlar tarafından daha fazla ilgi odağı haline gelmiştir. Özellikle günümüzde doğal ve kültürel kaynak değerlerinin turizm amaçlı bilinçsizce kullanılması, söylem ve eylem boyutunda yaşanan karmaşa ve belirsizlikler, yanlış ve yetersiz planlama ve yönetim yaklaşımları, turizm yatırımlarında yanlış ve gereksiz önceliklendirmeler gibi kaynak değerlerinin olumsuz etkilenmesine yol açmıştır. Ortaya çıkan bu olumsuzlukları en aza indirgenmesi için turizm kaynaklarının daha verimli kullanılması, ekoloji temelli çözümler üretilmesi, yerel kimliği ile ilişkilendirilmesi, paydaş katılımcılığın ve işbirliğinin sağlanması, yerel ölçekte ekonomik, sosyal ve çevresel gelişmesine katkıda bulunması gibi bir çok amaçların dikkate alınmasını gerektirmektedir. Oluşturulacak turizm veya kültür rotaları yereldeki turizm değerlerin korunması, yaşatılması, gelecek kuşaklara aktarılması, turizmin geliştirilmesi ve tanıtılması için önemli bir fırsat oluşturabilecektir. Silbergh vd. (1994)'e göre turizm rotaları, ziyaretçilerin eğitsel tecrübelerini arttıran, doğal ve kültürel çekiciliklerin bulunduğu bir bölgeye yönelik olarak yapılan ve ziyaretçilerin yürüyerek, motorlu araç ya da at sırtında gerçekleştirdikleri bir turizm biçimidir (aktaran Türker, 2013).

Turizm rotalarında temel amaç; her türlü alansal, noktasal ve çizgisel ölçekte turistik değer ve etkinlikleri birbirine bağlayarak bir bütünlük sağlamak, turizmi çeşitlendirerek noktasal alandan genele yaymak suretiyle daha cazibe hale getirmektir. Atabey ilç̧esi, doğal, tarihi ve kültürel değerleri nedeni ile koruma değerlerine ve ekoturizm potansiyeline sahiptir. Literatür araştırmalarına göre Atabey İlçesinde yapılan kazı çalışmaları sonucunda, Atabey illçesinin son Kalkolitik Çağdan MÖ 1000 yılı sonlarına kadar kesintisiz sayılabilecek yerleşmelere sahne olduğu anlaşılmaktadır (Türkiye'nin Gezi Rehberi, 2020). Bu durum yörenin önemli bir tarihi ize sahip olduğunun göstergesidir (Atabey Belediyesi, 2020). Atabey ilç̧esi; aynı zamanda ulusal ve uluslararası doğal ve kültürel kaynak değerleri potansiyeline sahiptir.

Bu çalışmanın amacı Isparta-Atabey İlçesinin ekoturizm potansiyelinin belirlenmesi ve turizm rotalarının oluşturulmasıdır. Bu amaçla turizm rotalarının oluşturulmasında rotaların taşıdığı doğal ve kültürel değerlerin ve öneminin vurgulanması esas alınmıştır. Sonuçta Atabey ölçeğinde kısa, orta ve uzun mesafeli turizm rotaları önerilmiştir.

\subsection{Turizm Tanımı ve Kapsamı}

Turizm; temel olarak bir ülkenin ulusal ölçekte tanınabilirliğini sağlayan, o ülkenin sosyal, ekonomik vb. anlamda kalkınmasının yanında ülkeler ve şehirlerarası kültürel etkileşimi, kardeşlik ve dostluk duygularının gelişmesine katkıda bulunan, farklı ülkeleri, onların kültürlerini öğrenmeyi destekleyen ve geçmişten günümüze kadar gelen köklü ve sürekli gelişebilen bir sektördür. Birçok bilimsel çalışmalarda turizm kavramının farklı şekillerde tanımlandığını görmek mümkündür. İlk olarak turizm kavramı; 1905 yılında E. Guyer Freuler tarafından "Ticaret, endüstri ve küçük sanatların ve ulaştırmanın gelişmesi üzerine, çeşitli özellikteki insanların iletişimleri sonucu olarak artan dinlenme, ortam değiştirme, çevre güzelliğine karşı duyulan eğilim ve yapılan etkinliklerden zevk almaya dayanan bir olayıdır" şeklinde tanımlanmıştır (aktaran Demir ve Çevirgen, 2006). Farklı kültürlerin tanınması, doğal, kültürel, tarihi zenginliklerin görülmesi adına turizm sektörü insan ve bu doğal, kültürel mekânların arasında bir lokomotif görevi üstlenmektedir ve aynı zamanda turizm rekreasyonel faaliyetlerin gerçekleştirilmesini sağlayan, insanın eğlenmek, gezmek, doğal ve kültürel güzellikleri keşfetmek adına yapılan gezidir. 
Günümüzde kentleşmenin artması, iklim değişiklikleri, yeşil alanların azalması, betonarme yapıların artması gibi birçok etken insanları doğal ve kültürel güzelliklerden mahrum etmektedir ve insanlara karşı büyük bir oranda psikolojik baskı uygulamaktadır. Bu baskılardan kurtulmak için kaçış noktası olan turistik geziler doğrultusunda insanlar kendilerini doğal alanlara eğilim göstermektedir. Bu nedenle doğal alanlara ve doğal mekânlara talep giderek artış göstermekle birlikte turizm faaliyetlerinin bilinçsizce kullanımı sonucu olumsuz etkileri de beraberinde getirmiştir. Özellikle doğal ve kültürel turizm kaynak değerlerinin zarar görmesi ve tamamen ortadan kalkması, çevresel kirlilik, görsel tahribat, iklim değişikliği ve geri dönüşü olmayan çevresel sorunları da beraberinde getirmiştir. Özellikle geçmişten günümüze yaygın olan kitle turizm anlayışı bu kaynak değerlerinin yanlış ve bilinçsizce kullanımı, doğal ve kültürel mekânların tahrip edilmesi, gibi birçok faktör, alternatif turizm arayışlarını ön plana çıkarmıştır. Günümüzde insanlar kitle turizmine bir önlem almak açısından doğa tabanlı, tüm yıl boyunca yapabilecekleri turizm aktivitelerini içeren ekoturizm etkinlikleri ön plana çıkmaktadır (Ünal Ankaya, Yazıcı, Balık ve Aslan, 2018). Turizm sektörü içinde, birbirine benzeyen çok sayıda turizm modeli ve alt türü vardır. Turizm; katılan birey sayısına göre, özellikle de ziyaret edilen doğal, kültürel ve tarihi mekânlara göre, amaçlara göre çeşitlilik göstermektedir. Turizm genel olarak kitle turizm ve alternatif turizm olmak üzere 2 grupta incelenmektedir. 1950'li yıllardan sonra gözlenmeye başlayan kitle turizmi; insanların turizme geniş ölçüde büyük kitleler halinde katıldıkları turizm aktivitesi olarak tanımlanmaktadır (Denk, 2019). Günümüzde doğal ve kültürel kaynakların yok olması ve tahrip edilmesinin önüne geçilmesi adına küçük gruplar ve bireysel olarak yapılan alternatif turizm çeşitleri ön plana çıkmaktadır. Birçok akademik çalışmalara bakıldığında alternatif turizm kavramsal olarak; kitle turizminin tam tersi olarak değerlendirilmektedir ve bu kapsamda doğaya duyarlı veya sürdürülebilirlik ilkelerine dayanarak geliştirilmesi gerekli turizm çeşitleri olarak da ifade edilmektedir (Baytok, Pelit ve Soybalı, 2017). Ekoturizm de bu alt türler arasında yer almaktadır.

\subsection{Ekoturizm Kavramı}

Geçmişten günümüze ekoturizm doğal alanlarda önemli bir ekonomik, sosyal ve ekolojik bir çıktı haline gelmiştir. Turistlerin doğal mekânlarda güçlü deneyimler yaşamaları için fırsatlar sunup doğal ve kültürel değerler hakkında bilgi edinme, biyolojik çeşitliliğin korunmasını ve yerel kültürün önemini ortaya koymaktadır (Drumm ve Moore, 2002). Bilimsel çalışmalara bakıldığında ekoturizm kavramı hakkında birçok kişi tarafından bazı tanımlamalar yapılmıştır ve ekoturizm kavramı ilk kez 1978'de Kenton Miller tarafından kullanılmıştır (Rahemtulla ve Wellstead, 2001). Tanımlamalara bakıldığında tüm tanımların ortak noktası; çevreye zarar vermeden, ondan yararlanma yöntemlerinin geliştirilmesi ve tüm yerli halkların kültürlerini yok etmeden, onların turizm faaliyetlerinden yararlanmalarının sağlanması, doğal alanlarda yapılan ve çevreyi koruyup yerel halkın refah seviyesini yükseltmeyi öngören bir turizm sektörüdür. Ekoturizm; günümüzde doğa odaklı turizm, çevreye uyumlu turizm gibi birçok kavramla aynı anlamı taşıyor gibi görünse de ekoturizm doğa turizminden farklı olarak doğal değerlerin yanı sıra kültürel değerlerin korunmasına da yoğunlaşmakta, yöre halkına gelir getirici faaliyetleri ve eğitim konularını da içermektedir (Kurdoğlu, Cırık, Lise, Çağlayan, Akkurt, Kandemi ve Welch, 2006). En yaygın kullanılan ekoturizm tanımı TIES tarafından "çevreyi koruyan ve yerel halkın refahını sürdüren, doğal alanlara doğru olan sorumlu seyahat" şeklinde yapılmıştır (Erdoğan, 2014). Ekoturizm; hassas, bozulmamış korunan alanlarda genellikle küçük ölçekte ve düşük etki vermeye çalışmaktadır. Bu mekânlarda yapılan etkinlikler doğrultusunda ziyaretçileri eğitme, doğal ve kültürel değerleri koruma, yerel toplumların doğrudan ekonomik gelişimini sağlama, farklı kültürler ve insan hakları için saygı duyulmasına teşvik etmektedir (Drumm ve Moore, 2002).

Ekoturizmin yerel topluluklar tarafından oluşturulduğunda ve yönetildiğinde ve amacının sadece yerel çevrenin sağlığı ve kültürel yapının korunması, tanıtılması, yerel toplum ihtiyaçlarının geliştirilmesi gibi özellikler dikkate alınarak yapıldığı sürece birçok faydası vardır. Bu ölçütler doğrultusunda gerçekleştirilen ekoturizm daha fazla ekoturistin çeşitli ortamlar hakkında bilgi edinmesini ve dünya çapında çevre bilincinin artması sağlanacaktır. Ayrıca ekoturizmi daha iyi anlamak ve yaşatmak için ekoturizmin kapsamı ve içeriğinin detaylı bir şekilde ortaya konulması, anlaşılması, nerelerde, niçin ve nasıl yapılacağı konusunda açıklık getirilmesi gerekmektedir (Gül ve Özaltın, 2007). 


\subsection{Ekoturizmin ilkeleri ve ekoturizm etkinlikleri}

Ekoturizm; temel olarak doğal ve kültürel değerleri koruyan, ulusal ve uluslararası boyutta tanınabilirliği sağlayan, çevre bilincini arttıran ve yerel toplumun ve birçok ilgili paydaşlara sosyo ekonomik katkılar sunan ve ayrıca sürdürülebilirlik kavramını göz önünde bulunduran bir turizm çeşidi olarak kabul edilmektedir. Bu gelişimin sağlanma sürecinde yerel halka, ekoturistlere ve ilgili paydaşlara çevre ve kültür bilincinin işlenmesi sağlanmalı, doğal ve kültürel kaynak değerlerine olan olumsuz etkisi düşük olmalı, ekolojik odaklı turlar olmalı, herkese hitap etmeli, yerel kimlik değerlerini yitirmeden tasarımlar yapılmalı, korumak için finansal faydalar sağlamalı, yerel halk için maddi getirisi olmalıdır (Çevre Bilinci Platformu, 2020).

Ekoturizmde temel hedefler; alanda mümkün olduğunca az iz bırakmak ve alanın mevcut durumunu geliştirmek için katkılar sunmak, kültürel, sosyal ve çevresel farkındalık yaratmak, hem ziyaretçiler, hem de yerel halk için olumlu tecrübeler sağlamak, koruma faaliyetlerine kaynak yaratmak, yerel halkın ekonomik kalkınmasına yardımcı olmak, relikt (soyu tükenen) ve endemik (sadece o yörede bulunan) ağaç ve bitki türlerine dikkat çekmek, somut olmayan kültürel mirası yaşatmak, yerel inisiyatifi harekete geçirmek, çevre bilincini tüm bireylere aşılamak, kaynakları verimli kullanmak ve yapılacak olan tüm faaliyetler için sürdürülebilirlik ilkesi şeklinde öngörülmektedir (Kentsel Strateji, 2020). Ayrıca ekoturizm etkinliklerinin gerçekleştirildiği doğal ve kültürel peyzaj değerlerinin sürdürülebilirliğinin, koruma-kullanma dengesinin sağlanması adına gerçekleştirilen ekoturizm etkinlikleri; (Kurdoğlu, vd., 2006; The International Ecotourism Society, 2020; Gül ve Özaltın, 2008)

- Doğa temelli olmalıdır,

- Planlama, gelişme, yürürlüğe koyma ve izleme safhalarında tüm ilgi gruplarını (bireyler, topluluklar, ziyaretçiler, tur operatörleri, sivil toplum kuruluşları ve hükümet kuruluşları) içermeli,

- Yerel topluluklar ve diğer ilgi grupları (tur operatörleri, turizm şirketleri, profesyonel rehberler) için adil, uzun vadeli ve sürdürülebilir gelir sağlamalı,

- Yenilenemez kaynakların minimum kullanımını öngörmeli, olumsuz çevresel ve sosyo-kültürel etkilerin en asgari seviyeye indirilmesi için aktiviteler hem ziyaretçilerin hem de yerel toplulukların sorumluluğunda düzenlenmeli,

- Yerel toplumun yapısını ve özgün kimlik değerlerini bozmadan geleneksel kültüre saygııı olmalı,

- Yerel topluluklara yönelik ekonomik kalkınma olanakları yaratmalı,

- Yerel halkın gelenek görenek ve manevi inançlarına saygılı olma ve bu konuda kültürel iletişimi güçlendirmelidir.

Çeşitli kaynaklar incelendiğinde turizm kendi içinde kitle turizmi (geleneksel, standart, büyük ölçekli turizm) ve alternatif turizm olmak üzere 2 gruba ayrılmaktadır. Alternatif turizm de kendi arasında; Kültürel, eğitsel, bilimsel, macera, agroturizm (kırsal, çiftlik vb.) şeklinde 5 gruba ayrılmaktadır ekoturizm de bunların hepsini kapsamaktadır. Ekoturizm çeşitli ölçütlere göre gruplandırılır. Bu ölçütler turizm kullanılan araçlar (bisiklet, balon, raft, at vb.), gidilen yerin doğal ve kültürel peyzaj değerleri (dağ, yayla, mağara), yapılan etkinliğin özelliği (akarsu, av, bilim, trekking) gibi çeşitlilik göstermektedir (Akpınar ve Bulut, 2010). Ekoturizm faaliyetlerini uygulayan, hizmet veren ve hizmet alan tüm paydaşlar yukarıda belirtilen ekoturizm ilkelerini benimsemesi gerekmektedir. Özellikle bu etkinliklerin gerçekleştirilmesi için ortaya konulan mekanlar doğal ve kültürel peyzaj değerlerine düşük etkili ekolojik ve ilgili meslek disiplinleri tarafından tasarlanmalıdır. Bu tasarımlar ortaya konulurken birinci öncelik tamamen sürdürülebilirlik ilkesinin benimsenmesi ve çevreci bir yapıya ulaşılmasıdır ve yenilenebilir enerji kaynakları (rüzgâr enerjisi ve güneş enerjisi gibi) tercihi yapılmış ve tüm yapı malzemelerinin yerli ürün olarak tedarik edilmesi gerekmektedir.

Ayrıca yeşil bina yaklaşımına sahip bir çalışma ve disiplinle tüm aşamalar yerine getirilmelidir. Doğayı, eğlenmeyi, rekrasyonel ve sosyal etkinlikleri gerçekleştirmeyi, ruhsal yönden rahatlamayı sunan turizm tesisleri tasarımlarıyla, görselliğinin yanında fonksiyonel, işlevsel, estetik ve hatta ekolojik oluşu, alanların daha etkin kullanılmasını ve bu alanlara talebin artmasını sağlar. Peyzaj çalışmalarının yarattığı düzen ve uyum, oluşturulan renk cümbüşü mekânların cazibesini artırır. Bu nedenle ülke 
turizminde peyzajın ve peyzaj mimarının önemli bir katkısı bulunmaktadır (Peyzaj Mimarları Odası PMO, 2020).

\subsection{Turizm Rotaları}

Günümüzde kültürel ve doğal mirasın korunması ve ekonomik potansiyelin değerlendirilmesi için 'rota planlaması', yerel ve özgün değerleri açısından zengin bölgelerin gelişme politikalarında önem kazanmaya başlamıştır. Fiziksel çevredeki geniş kapsamlarına bağlı olarak kültür rotaları, koruma ve işlevlendirme uygulamalarının bölge ölçeğinde ve bütünsel bir anlayışla geliştirilmesine olanak sağlarken, aynı zamanda yerel ölçekte örgütlenme, işbirliği ve sahiplenmenin de önünü açmaktadır (Çekül, 2014). Alternatif turizm türlerinin ortaya çıkmasıyla birlikte, turistlerin çevre ve doğaya daha az zarar veren turizm faaliyetlerine yönelmeleri, turizmden beklentilerinin artması, turizm çeşitlerindeki artışlar turizm endüstrisini oldukça farklılaştırmıştır (Türker, 2013). Turizm rotaları muhtemelen toplumdaki doğal ve kültürel peyzaj değerlerin daha fazla duyarlılığını ve farkındalığını elde etmek için en iyi araçlardan biridir, bu durum özellikle okul çağındaki çocuklarda çevre ile ilgili konularda bilgiyi güçlendirmeye ve geliştirmeye sağlamaktadır (Barrena, Laporte, Ortega ve Pozo, 2016). Turizm rotaları gibi; bir ana tema kapsamında birbirinden farklı bir dizi çekiciliği bir araya getiren ve ziyaretçilerin bir yerden başka bir yere seyahat etmesi nedeniyle bölgesel turizmi harekete geçiren bir seyahat çeşididir (Lourens, 2007). Turizm rotaları; birbirinden kopuk turizm faaliyet alanlarını birbiriyle kombine ederek ortaya sunmaktadır, bütünlük ilkesini benimseyerek destinasyonların ziyaretçiler tarafından çekiciliğini arttırmaktadır. Rotalar; gerek doğal, kültürel ve tarihi mirasın korunması ve sunumunu bölgesel ölçekte destekleyen, gerekse yatay işbirliği zeminlerine ve yerel kalkınmaya olanak tanımaktadır. Turizm rotaları, turizm açısından doğal ve kültürel değerlere sahip mekânların ve o mekanlarda öngörülen etkinlikleri bütüncül bir kurgu ile bizlere sunan ve birçok ilgi çekici noktaları birbiriyle kombine eden, yerel halkın kalkınmasını ve o yörenin ulusal ve uluslararası boyutta tanınmasına katkılar sunan, yol ağlarıdır. Ayrıca turizm rotaları; turist güzergâhlarını iyileştirmek ve yeni turistik destinasyonları tanıtmak gibi işlevlere sahiptir. Rotalar, hem kamu sektörü hem de özel sektör tarafından, turizmden gelir elde etmek amacıyla bölgenin ve turizm ürününün çekiciliğini artırmak için geliştirilmektedir (Meyer, 2004).

\subsection{Turizm rotaların amaçları ve faydaları}

Ekoturizm; günümüzde en hızlı gelişme gösteren turizm çeşitleri arasında yer almaktadır. Bunun en önemli nedenlerinden biri; nüfus yoğunluğu fazla olan kentsel bölgelerde, hava ve gürültü kirliliği sorunları ile birlikte yaşamak durumunda olan insanların mekân ve sosyal aktivite değişikliğine ihtiyaç duymaları, bu ihtiyaçların da turizm talebine yansıması ile yeni arayışların gündeme gelmesidir. Ayrıca uzun yıllar dünya turizm sektörüne ek olarak kitlesel turizmin, doğal ve kültürel mekânlar üzerindeki olumsuz etkilerinin artık farkına varılması ve artan turizm bilinci ile birlikte turizm sektörünün sürdürülebilirliği amacıyla kitlesel turizme alternatif olanakların tercih edilmesi şeklinde açıklanabilir (Akın, 2016).

Turistler için; turistik alanları gezmek, keşfetmek ve orda vakit geçirmek adına bir rehber ve yol haritası niteliği taşıyan turizm rotaları, ekoturizm rotaları gibi günümüzde birçok kavram yaygınlaşmaktadır. Rotalar, turistler için ulaşım aracı olup doğal ve kültürel turizm değerlerini kontrollü ve bir rehber niteliğinde kullanmalarını sağlamaktadır. Turistler açısından rotanın önemi; eğer organize turlara katılmışlarsa rotadaki güzergâhları ve yolları seçme şanslarının olmayışı; tatil programını kendileri hazırlamışlarsa, istedikleri rotayı seçme şansına sahip olmalarıdır (Baykal, 2015).

Turizm rotaları; bir bölgenin doğal ve kültürel turizm değerlerini ortaya koyup hem ulusal hem de uluslararası boyutta tanınmasını sağlayan, o yöreye ait yöresel ürünlerin, yöresel kıyafet, gelenek ve görenekleri, somut olmayan kültürel değerlerin ve tarihi izlerin marka imajını geliştirir, turizm rotasının oluşturulduğu bölgede yaşayan yerel halkın geçimine katkıda bulunmanın dışında; Meyer (2004) ve Lourens (2007)'e göre turizm rotaların sağladığı faydalar aşağıdaki gibi sıralanmıştır;

- Turizm rotaları bir rota üzerindeki/bir bölgedeki çok çeşitli faaliyetleri, doğal ve kültürel turistik cazibe noktalarını bir araya getirir. 
- Tek başına herhangi bir çekiciliği olmayan ve yetersiz kaynakları nedeniyle pazarlama çalışmaları ve turizm gelişimi sağlanamayan küçük yerleşim yerleri ve köylerin pazarlanmasına katkılar sağlamaktadır.

- Bölgedeki girişimcilerin gelişmesini teşvik eder.

- Yörede ziyaretçi kalış süresini uzatır, ziyaretçi harcamalarını arttırır.

- Rotalara ziyaretin artması ile birlikte turistik faaliyetlere, alışveriş ve yeme içme gibi eylemlerin artmasına da neden olabilmektedir.

- Destinasyonların çekiciliğini arttıır ve gelişmesine katkılar sunar.

- Turistler tarafından fazla bilinmeyen çekiciliklerin turistler tarafından tanınmasını sağlar.

- Kırsal alanlarda ekonomik, sosyal ve kültürel yönden yerel halkın gelişmesine katkılar sunar.

- Bölgede doğrudan ve dolaylı istihdam artışı yaratır,

- Turizm rotaları turistleri bir bölgeye çekmenin yanı sıra, çeşitli ilgi çekici yerleri birbirine bağlamaktır (Meyer, 2004).

- Turizm rotaları, sınır aşan işbirliği, işbirlikçi hedef pazarlaması, ürün geliştirme, kamu-özel sektör ortaklıkları ve doğal ve kültürel miras koruma için fırsatlar yaratır (UNWTO, 2014).

- Turizm talebini ve gelirini tüm yıl boyunca ve bölge geneline yayarak zenginliğin bölgesel dağılımı, önemli cazibe merkezleri üzerindeki baskının azaltılması ve mevsimsellik konusunu ele almaktadır (UNWTO, 2014).

- Turizm rotaları; birden fazla ülke üzerinden geçerek aynı bölge veya ülkede kısa rotalar üzerinden büyük mesafeler boyunca turizmi geliştirilebilir.

- Daha fazla esneklik, keşif, öğrenme ve temas gerektiren zenginleştirici deneyimler arayan gezginler tarafından turizm rotalarına talep artmaktadır ve böylelikle turizm rotalarının geliştirilmesi önem kazanmaktadır.

\subsection{Turizm rotaları oluşturma ve tasarım ilkeleri}

Turizm rota sistemleri; turistik gezileri organize etmek, yönetmek ve planlamak için çok popüler uygulamalar haline gelmektedir. Günümüzde kültürel mirasın korunması ve yaşatılması için yaygın olarak kullanılan kültür rotaları; koruma ve işlevlendirme uygulamalarının bölge ölçeğinde ve bütünsel bir anlayışla geliştirilmesine olanak sağlamaktadır (Çekül, 2014). Ayrıca turizm rotaları tasarlanırken turist profili, zaman, ilgi alanı, zorluk derecesi gibi değişkenler de rota tasarımı ve kullanımını etkileyen konulardır (Çekül, 2014).

Turizm rotaları oluşturulurken rota boyunca turizm etkinliğinin yapılacağı mekânlar, sulak alanlar, dik yamaçlar, özel mülkiyete ve Orman Bölge Müdürlüğüne ait araziler, tarım alanları, arkeolojik alanlar, doğal ve kültürel sit alanları, gibi faktörler rota planlamasında çok etkilidir. Bu faktörleri birlikte değerlendirmek ve en uygun rotaları sayısal hale getirmek üzere çeşitli yöntemler (fotogrametri, survey, klasik arazi çalışmaları, hava fotoğraflarından yer tayini gibi) kullanılmaktadır (Selim ve Sönmez, 2017).

Günümüzde teknolojinin gelişmesiyle her kesim için ulaşılabilir, güncel, turizm rotaların elde edilmesi mümkündür. Genellikle turizm rotaları oluşturulurken; turizm yapılacak mekânların çok boyutlu olarak anlaşılmasına ve analizine imkân veren CBS teknolojileri kullanılmaktadır (Selim ve Sönmez, 2017). Turizm rotalarının oluşturulmasında mekân tasarımı oldukça önemli olup, çekici "doğal ortamlar" yaratmak için peyzaj mimarları görev verilmektedir. Bu mekanların oluşturulmasında ekoturizmi sürdürülebilir kalkınma çerçevesinde algılamak; yapılacak olan turizm etkinliklerini ekolojik ve ahlaki ilkelere dayalı olarak yürütmeyi ve dolayısıyla turizme ve yerli halka çok boyutlu katkıları beraberinde getirecektir (Arslan, 2005).

\section{Materyal ve Yöntem}

\subsection{Materyal}

Çalışmanın ana materyalini Isparta Atabey ilıçesi doğal ve kültürel peyzaj değerleri oluşturmaktadır. Çalışma alanına ait tüm, doğal, sosyal ve kültürel peyzaj değerler ayrı ayrı birer materyal olarak incelenmiştir. Çalışmada Atabey İlçesine ait sayısal haritaların elde edilmesi için Küresel Dijital Yükseklik Modeli (GDEM) verileri ve uydu görüntüleri kullanılmıştır. Atabey ilıçesinin doğal ve kültürel 
turizm değerlerini sayısal hale getirmek adına Coğrafi Bilgi Sistemleri Genel Müdürlüğü tarafından ortaya konulan "Coğrafi Veri Servis Havuzu (CVSH) " veri temini sağlanmıştır ve tüm bu işlemlerin gerçeklemesi için araştırmada, elde edilen verileri çakıştırmak, veri tabanı oluşturmak ve depolanan bilgiyi sorgulamak için Coğrafi Bilgi Sistemleri içinde yer alan ArcGIS 10.7 programı kullanılmıştır. Çalışmada yerli ve yabancı kaynak olmak üzere, yayınlamış olan makaleler, bildiriler, belgeler, akademik çalışmalar, planlama rehberleri, güncel internet araştırmaları, kitaplar, konuyla ilgili güncellenmiş web siteleri, raporlar, yayınlar, yapılan benzer çalışmalar ve görsel malzemelerden materyal olarak yararlanılmıştır.

\subsubsection{Atabey İlçesinin genel özellikleri}

Isparta'ya 21 km uzaklıkta olan Atabey ilçenin Yüzölçümü 202 km²‘dir. İlçenin kuzeyini ve batısını Barla Dağı kuşatmaktadır ve dağlarında yer yer meşe korulukları bulunmaktadır. Atabey illçesi'nin kuzeyinde Senirkent ve Uluborlu, batısında Gönen, güneyinde Isparta Merkez İlçe, doğusunda Eğirdir İlçeleri bulunmaktadır. Güneyde Bozanönü Ovasının bir bölümü illçe toprakları içinde kalmaktadır. Isparta ovasının kuzeye doğru uzantısı olan bu ova deniz yüzeyinden 950 metre yükseklikte olup, Isparta ovasından Arap tepe, Bozanönü, Erenler ve Çeşme tepeleri ile ayrılır. Ovanın dağlara doğru yükselen kesimlerinde yer yer meşe korulukları bulunmaktadır.

İslamköy başta olmak üzere Atabey İlçesindeki mevcut gül bahçelerinde gül yetiştirilmekte ve fabrikalarda işlenmektedir. 2019 yılı nüfus sayımlarına göre Atabey İlçesinin toplam nüfusu 5.761'dir ve bu oranın 2845 'i erkek nüfusu $(\% 49,38), 2916$ 'sı kadın nüfusu $(\% 50,62)$ oluşturmaktadır (Atabey Nüfusu, 2020).

Atabey İlçesinin topoğrafik özellikleri; dört tarafı yüksekliği 1500-2500 m arasında değişen dağlarla kaplı ve ortalama kotu $950 \mathrm{~m}$ ve taban arazi şeklindedir. İç Anadolu Bölgesi ile Akdeniz Bölgesi arasında bir geçit bölgesi konumunda olan Atabey ilçesi hem karasal hem de Akdeniz iklim özelliklerinin yansıtmaktadır. İlçenin yıllık ortalama sıcaklık miktarı $12,0{ }^{\circ} \mathrm{C}$ ve yıllık ortalama yağış miktarı 560 mm'dir. Atabey ilçesinin jeolojik bakımdan diğer ilçelere göre daha genç bir zemin üzerinde yer almaktadır. Atabey ilçesinde en eski formasyon jura kireçtaşı olduğu bilinmektedir. Ayrıca şeyl, tabakalanmış çört, radiolarit, marn ve kireçtaşı da bulunmaktadır. Lütesiyen kireçtaşları koyu gri ve açık kahve renkli olup Atabey ovasının güneybatısında ve ortasında küçük mostralar halinde olduğu görülmektedir ve Pliokuaterner tüm ovayı kaplayıp, genellikle çakıl, kum ve kilden oluşmuştur (Parladır Karcı ve Uçar, 2018). Illçenin ekonomisi tarım ve hayvancılığa dayanmaktadır ve ayrıca ilçede mermer ocakları da bulunmaktadır. Özellikle, 1970 yılından sonra, Atabey ilçesinde ve çevresindeki yerleşmelerde çeşitli sanayiler kurulmaya başlanılmıştır (Isparta il Kültür ve Turizm Müdürlüğü, 2020).

\subsubsection{Atabey İlçesinin sahip olduğu doğal ve kültürel turizm değerleri}

Atabey ilçesi doğal ve kültürel turizm değerleri açısından önemli zenginliklere sahip olmasının yanında Antik dönemlerde de önemli bir bölge olduğu görülmektedir. Antik Çağ'da Agrai veya Agpia olarak bilinen Atabey yöresi MÖ 334'te Büyük İskender'in egemenliği altına girmiştir. Isparta Valiliği tarafından yayınlanmış illçe tanıtımlarına göre Atabey ilçe sınırları içinde en eski yerleşim yeri olarak Pembeli Höyük'te Erken Kalkolitik malzemesi ele geçirilmiştir. Harmanören Köyü’nde bulunan Göndürle I ve Göndürle II Höyüklerinde yapılan kazılarda çıkan malzemelerin, Illk Tunç Çağ Dönemine ait olduğu bilinmektedir. Atabey'in Bayat Köyü'nde Seleukeia Sidera Antik Kenti bulunmaktadır. Isparta ve civarının 1204'te III. Kılıç Arslan zamanında fethedilmesinin arkasından, Atabey Anadolu Selçuklular'ın uç kumandanlarından Gazi Ertokuş Bey tarafından Bizanslılardan alınmış ve bir üs haline getirilmiştir. Atabey, 1390’lı yıllarda Osmanlı hâkimiyetine girmiştir (Isparta Valiliği, 2020).

İlçe sınırları içinde bulunan başlıca doğal, tarihi ve kültürel turizm değerleri; Harmanören (Göndürle)'de meydana çıkartılan 41 Küp Mezar, Sidera Bayat Harabeleri, Ertokuş Medresesi, Sinan Camii, Feyzullah Paşa Cami, Burhanettin Paşa Camii, Antik Su yolu, Koca Tepecik Mevki Yerleşim alanı, Seleukei Antik Kenti, Kırık Minare (Cuma ) Cami, Atabey Kısık Vadisi, Atabey Göleti, Atabey Çayırlı Mescit, Atabey At Çiftliği, Onaç Çeşmesi, Atabey Orta Hamamı, Atabey Aşağı Hamam, Atabey Belediye Hamamı (Yukarı Hamam, Mimar Hamamı, Çeşme Mah. Hamamı), Veli efendi türbesi, 19 
adet tescilli bina, Balıklı çeşme kalesi, Odalarüstü Mevki Kaya Mezarı, Yassıardıç kale kalıntısı, Pamuklu Höyük, Alaca Mescit, Sırçalı Nekropolü, Barla dağı şeklindedir.

Atabey ilçesine bağlı İslamköy kasabasının turizm değerleri ise; Topalınoğlan Nafiz İsmail Çeşmesi, Hacı Kavas Çeşmesi, Hıdır Cami Çeşmesi, Park Çeşmesi, Ağaların Çeşmesi, Hacı Ömer Sarnıcı ve Çeşmesi, Arapoğlu Çeşmesi (Kösekâhyaların Çeşme), Hatıpların Çeşmesi, Aşağı Harman Çeşmesi, Goca Cami (Rüstem Paşa Cami) Çeşmesi, Cıgalların Çeşmesi, İslamköy Tarihi Hamamı, Hızır Cami veya Hıdır Cami, Rüstem Paşa Cami, Yeni Cami (Aşağı Harman Cami), Şehriban Hatun Cami, Arapoğlu Cami, Orta Mescit Cami (Koçakların Mescit), Ağaların Mescit, Çalça Dede Türbesi, Gökmen Dede (Çıtlık Dede) Türbesi, Koyun Dede Türbesi, Çiftçi Dede Türbesi, Goca Cami Önündeki Dede Türbesi, Karaman Ailesi Bahçesindeki Dede Türbesi, İzzet Ağanın Mezarı, Deliklidaş (íslamköy Mezarlığında), Toplam 43 (1 sarnıç, 2 çeşme, 40 ev) adet tescilli yapılar, Süleyman Demirel Demokrasi ve Kalkınma Müzesi, Süleyman Demirel Devlet Anıt Mezarı (Çalca Tepe), Tarihi Yağhaneler (Ahmet Okkalı, Aziz Okkalı, Sezgin Yılmaz ve Hüseyin Aykut yağhaneleri), Tarihi su sarnıcı, Alaadin Öztürk Sabunhanesidir (Gül, Akın ve Pekgöz, 2019).

Atabey İlçesi aynı zamanda Konya-Antalya kervanyolu ve Kuzey Pisidia antik yolları üzerinde yer almaktadır (Demirci, 2014). Wikiloc (2020)'ye göre Atabey ilçesinde 11 adet turizm rotası olduğu tespit edilmiştir. Bu rotalar; Çifte Göletler Kısa Parkur, Çifte Göletler Uzun Parkur, Ertokuş MedresesiEğirdir-Anamas-Yaylası-Pınargözü Parkuru, Kısık Vadisi Parkuru, Atabey-Gönen yaylası Parkuru, Atabey - Anadolu Mahallesi Parkuru, Atabey kros Parkuru, Atabey - Isparta Parkuru, Atabey gölet 1 Parkuru, Atabey - Isparta Parkuru ve son olarak Çifte barajlar Parkurudur. Isparta Atabey ovasında kuş gözlemciliği ekoturizm değeri olabilecek çeşitli kuş türlerine rastlanmaktadır. Atabey Ovası'nda 16 takıma ait 33 familyadan 99 kuş türü tespit edilmiştir. Bu kuş türlerinden 8'i su kuşu olup, sulak alanlarda yaşamaktadır (Aksan ve Mert, 2016). Bu kuş türleri arasında IUCN uluslararası kırmızı listede Circus macrourus (S. G. Gmelin, 1770) NT (Neredeyse tehdit altında) ve Falco cherrug (Gray, 1834) EN (Tehlikede) kategorisindedir (IUCN, 2015; Eken, Bozdoğan, İsafendiyaroğlu, Kılıç ve Lisa, 2006).

Isparta-Atabey karayolu üzerinde şehir merkezine $18 \mathrm{~km}$ uzaklıkta, Bayat Köyü sınırları içerisinde bulunan tepeden yamaç paraşütçülüğü faaliyeti yapılabilmektedir (Isparta Valiliği, 2020). Ayrıca Atabey ilçe merkezinde yer alan Agrae kenti modern ilçe merkezi altında kalmıştır. Birkaç mimari parça dışında kentten herhangi bir kalıntı yoktur. İlçe merkezinin kuzeybatısında Kapıcak Köyü yakınında Parlais (Barla) ve Prostanna (Eğirdir) şehirlerinin sınırlarını belirleyen bir sınır yazıtı bulunmaktadır. Agrae Bizans döneminde Seleukeia ile birlikte bir piskoposluk merkezidir (Isparta il Kültür ve Turizm Müdürlüğü, 2020).

\subsection{Yöntem}

Bu çalışmada Atabey ilç̧esinin doğal ve kültürel turizm değerleri alansal, noktasal ve çizgisel olarak ArcGIS 10.7 programında altık haritalara işlendikten sonra mevcut ulaşım yolları, ulaşım mesafeleri dikkate alınarak rotalar belirlenmiştir. Atabey ilçesinin mevcut toprak, patika ve asfalt yolları sayısal verilerle doğal ve kültürel turizm noktaları ile ilişkilendirilmiştir. Turizm rotaları Network (Ağ) Analiz yöntemiyle yapılmıştır. Rotalar oluşturulurken izlenen yol şu şekilde sıralanabilir; yol ağı verisi- veri tabanı oluşturma- ağ topolojisi oluşturma- ağ veri seti oluşturma- ağ analizi-en uygun rotadır.

Bu rotaların belirlenmesinde ekoturizm kaynak değerleri ve içeriği, ulaşım süresi, ulaşım mesafesi, ulaşım tipi, mevcut yolun varlığı, eylemlerin karakteri gibi faktörler dikkate alınmıştır. Bu kapsamda ziyaretçilerin yaya olarak yürümek suretiyle mesafe ve süre ilişkisi dikkate alınmıştır. Bilimsel olarak bir yayanın normal koşullarda yürüyerek 1 saatte ortalama $4 \mathrm{~km}$ yol kat edilebilmektedir. Buna göre kısa mesafeli rotalar 2 saatten az, orta mesafeli rotalar 2- 6 saat arası ve uzun mesafeli rotalar ise 6 saatten fazla sürede kat edilecek şekilde kurgulanmıştır. Ayrıca rotalar üzerindeki etkinlik noktalarında hangi faaliyet veya eylemlerin yapılacağına yönelik öneriler de öngörülmüştür.

Önerilen rotalarda yaya olarak veya bisiklet, atla, özel araçla veya toplu araçlarla ulaşım sağlanması mümkün olabilecektir. Rotalarda öngörülen doğal ve kültürel ekoturizm noktalarında yapılacak olan faaliyetler/eylemler ortaya konulmuştur. Bu faaliyet tipleri belirlenirken ekoturizm ilkeleri göz 
önünde bulundurulmuştur ve ekoturizm odaklı yapılan bu etkinlikler turizm rotası üzerinde bulunan her bir nokta için noktanın mekânsal özelliği göz önünde bulundurularak önerilmiştir.

\section{Bulgular ve Tartışma}

\subsection{Atabey ilıçesi turizm rotalarının oluşturulması}

Atabey ilıçesinin doğal ve kültürel peyzaj değerleri dikkate alınarak kısa, orta ve uzun mesafeli olmak üzere 3 adet turizm rotaları oluşturulmuştur. Bu bağlamda Atabey ilç̧esinin mevcut ulaşım ağı, ArcGIS 10.7 programında sayısal hale getirilmiş harita sayısallaştırıldıktan sonra üzerinde düğüm-çizgi topolojisi oluşturulmuştur (Şekil 1) ve oluşturulan bu topoloji ile her bir düğüm noktasının ve bu düğüm noktalarını birleştiren çizgilerin öznitelik bilgileri belirlenmiştir ve bu ulaşım ağı içinde toprak yol, asfalt yollar ve patika yolları seçilerek ağ analizi için gereken Feature dataset özelliğindeki veri tipine dönüştürülmüştür daha sonra oluşturulan veri tabanındaki çizgisel verilerdeki hataların düzeltilmesi için topoloji uygulanmıştır ve son olarak Ağ analizi komutu çalıştırılarak bu ulaşım sistemi rota planlaması için hazır hale getirilmiştir. Rotalar oluşturulurken izlenen yol; yol ağı verisi $\rightarrow$ veri tabanı oluşturma $\rightarrow$ ağ topolojisi oluşturma $\rightarrow$ ağ veri seti oluşturma $\rightarrow$ ăg analizi $\rightarrow$ en uygun rota şeklindedir. Atabey ilçesinin doğal ve kültürel tüm turizm değerlerine ulaşımı sağlanan turizm rota planlaması yapılmıştır. Ayrıca rotalar üzerinde bulunan doğal ve kültürel turizm noktalarında belirli faaliyetler/eylemler öngörülmüştür.

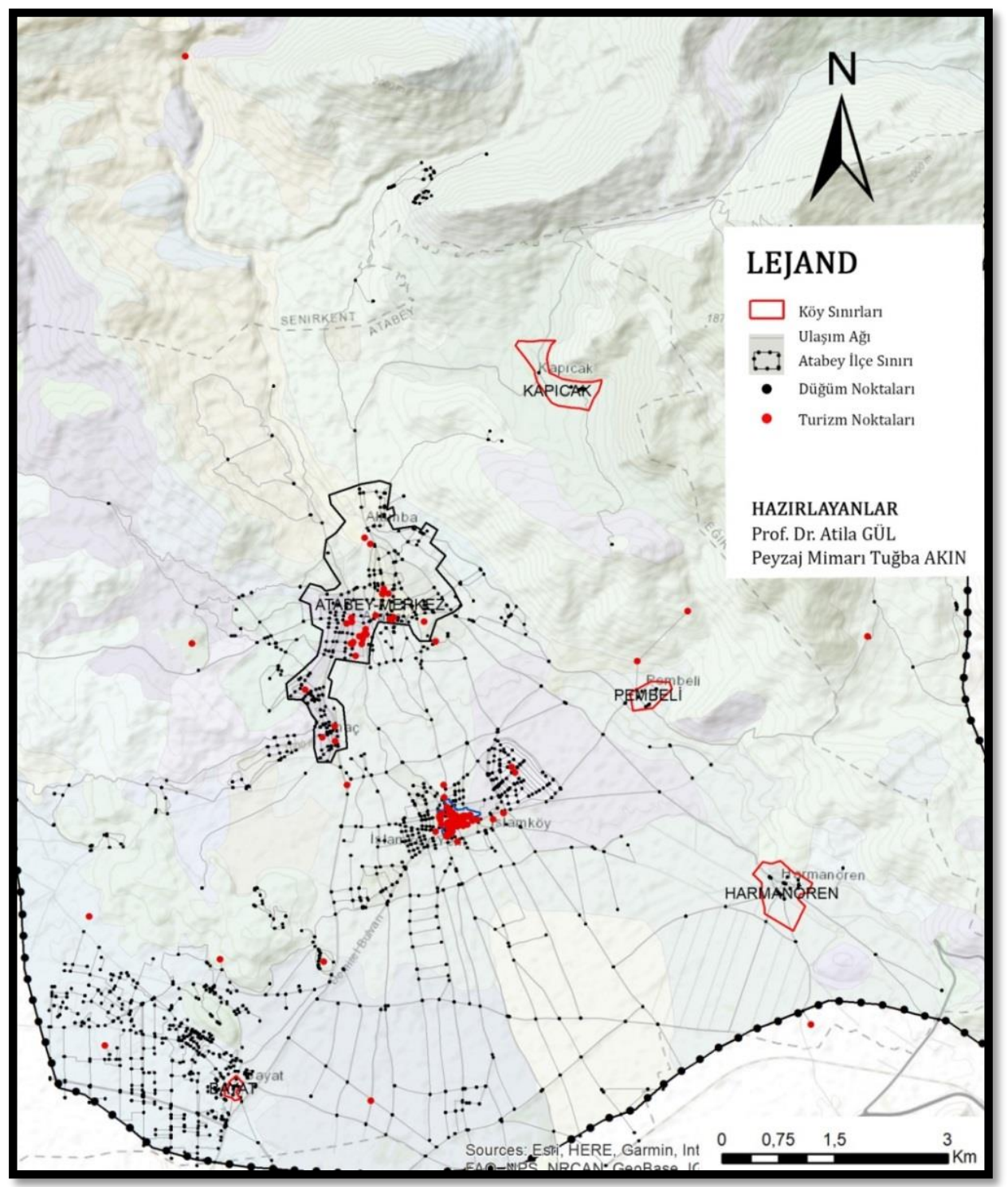

Şekil 1. Atabey ilçesi ulaşım ağı ve düğüm noktaları 
Kısa Mesafeli Rota (KMR): Atabey illçesinde önerilmiş olan bu rota $9 \mathrm{~km}$ uzunluğunda olup yürüyüş ekinliği ile günde yaklaşık 4-8 saat arası sürecek bir rotadır. Rota üzerindeki noktalar şu şekildedir; Onaç çeşmesi, Atabey Aşağı Hamam, Kırıkminare (Cuma) Cami, Yılmaz Cami, Atabey göleti, 9 adet tescilli ev, Burhanettin Paşa Cami, Atabey Orta Hamamı, Ertokuş Külliyesi Ertokuş Medresesi, Feyzullah Paşa Cami, Şeyh Veli Efendi Türbesi, Atabey çayırlı mescit ve Atabey at çiftliği olarak belirlenmiştir. Öneri turizm rotası ve turizm noktaları Şekil 2'de gösterilmiştir. Oluşturulan öneri rotasıyla ilgili bilgiler (Rota noktaları, nokta üzerinde yapılacak etkinlikler ve mekânsal tasarım önerileri Çizelge 1'de gösterilmiştir.

Çizelge 1. Kısa mesafeli rota noktaları, yapılacak etkinlikler ve mekânsal tasarım önerileri

\begin{tabular}{|c|c|c|}
\hline Rota Noktaları & Yapılacak Etkinlik & Mekânsal Öneriler \\
\hline $\begin{array}{l}\text { KMR-1=Onaç } \\
\text { Çeşmesi }\end{array}$ & $\begin{array}{l}\text { Çeşme kültürünü yaşama, tarihe yolculuk, } \\
\text { çeşmeyi bilinçli kullanıma yönelik çalışmalarda } \\
\text { bulunma, fotoğraf çekme ve doğal kaynağı } \\
\text { kullanma ve koruma. }\end{array}$ & $\begin{array}{l}\text { Onaç çeşmesinin doğal yapısı dikkate alınarak korunmalı ve } \\
\text { yöreye ait malzemeler kullanılarak çeşmenin onarılması ve } \\
\text { projelendirilmesi gerekmektedir. }\end{array}$ \\
\hline $\begin{array}{l}\text { KMR-2=Atabey } \\
\text { Aşağı Hamam }\end{array}$ & $\begin{array}{l}\text { Tarihi hamamın restore çalışmalarına katılma, } \\
\text { Hamam kültürünü yaşama ve yaşatma, } \\
\text { hamamın yapım aşamasında görev alma ve } \\
\text { hamamın tarihi hakkında yapılan çalışmalara } \\
\text { katılma. }\end{array}$ & $\begin{array}{l}\text { Restore çalışmaları gerekli meslek disiplinlerince ortaya } \\
\text { konulmalıdır ve malzeme konusunda mekanın özgün değerini } \\
\text { yitirmeyecek ekolojik, ekonomik ve estetik kriterler göz } \\
\text { önünde bulundurularak seçim yapılmalıdır. }\end{array}$ \\
\hline $\begin{array}{l}\text { KMR-3=Kırıkminare } \\
\text { Cami }\end{array}$ & $\begin{array}{l}\text { Manevi yönden iç rahatlatma, caminin çevre } \\
\text { düzenlenmelerine ve katkıda bulunma. }\end{array}$ & $\begin{array}{l}\text { Caminin peyzaj tasarım projesi ortaya konulmalı ve } \\
\text { ziyaretçilerin alanda daha rahat, kontrollü vakit geçirebilmeleri } \\
\text { için mekânlar tasarlanmalıdır. }\end{array}$ \\
\hline KMR-4=Yılmaz Cami & $\begin{array}{l}\text { Manevi yönden iç rahatlatma, caminin çevre } \\
\text { düzenlenmelerine ve katkıda bulunma }\end{array}$ & $\begin{array}{l}\text { Caminin peyzaj tasarım projesi ortaya konulmalı ve } \\
\text { ziyaretçilerin alanda daha rahat, kontrollü vakit geçirebilmeleri } \\
\text { için mekânlar tasarlanmalıdır. }\end{array}$ \\
\hline $\begin{array}{l}\text { KMR-5=Atabey } \\
\text { Göleti }\end{array}$ & $\begin{array}{l}\text { Piknik yapma, olta balıkçılığı, manzara izleme, } \\
\text { bitki gözlem ve inceleme, kuş gözlemi, fotoğraf } \\
\text { çekme. }\end{array}$ & $\begin{array}{l}\text { Öncelikle gölet ve çevresinin peyzaj tasarım çalışmalarının } \\
\text { yapılması, gölet çevresine ziyaretçilere yönelik fonksiyonellik } \\
\text { kazandırılmalıdır. }\end{array}$ \\
\hline $\begin{array}{l}\text { KMR-6= } \\
\text { Burhaneddin Paşa } \\
\text { Cami }\end{array}$ & $\begin{array}{l}\text { Manevi yönden iç rahatlatma, caminin çevre } \\
\text { düzenlenmelerine ve katkıda bulunma. }\end{array}$ & $\begin{array}{l}\text { Caminin peyzaj tasarım projesi ortaya konulmalı ve } \\
\text { ziyaretçilerin alanda daha rahat, kontrollü vakit geçirebilmeleri } \\
\text { için mekânlar tasarlanmalıdır. }\end{array}$ \\
\hline Tescilli Evler & $\begin{array}{l}\text { Restorasyon çalışmalarına katılma, çevre } \\
\text { düzenleme, fotoğraf çekilme. }\end{array}$ & $\begin{array}{l}\text { Restore çalışmaları gerekli meslek disiplinlerince ortaya } \\
\text { konulmalıdır. }\end{array}$ \\
\hline $\begin{array}{l}\text { KMR-7= Atabey } \\
\text { Belediye Parkı }\end{array}$ & $\begin{array}{l}\text { Piknik yapma, dinlenme, parkın çevre } \\
\text { düzenlenmelerine katkıda bulunma. }\end{array}$ & $\begin{array}{l}\text { Parkın restore ve peyzaj tasarım projesi ortaya konulmalı ve } \\
\text { ziyaretçilerin alanda daha rahat, kontrollü vakit geçirebilmeleri } \\
\text { için mekânlar tasarlanmalıdır. }\end{array}$ \\
\hline $\begin{array}{l}\text { KMR-8=Atabey } \\
\text { Orta Hamamı }\end{array}$ & $\begin{array}{l}\text { Tarihi hamamın restore çalışmalarına katılma, } \\
\text { Hamam kültürünü yaşama ve yaşatma, } \\
\text { hamamın yapım aşamasında görev alma ve } \\
\text { hamamın tarihi hakkında yapılan çalışmalara } \\
\text { katılma. }\end{array}$ & $\begin{array}{l}\text { Restore çalışmaları gerekli meslek disiplinlerince ortaya } \\
\text { konulmalıdır ve malzeme konusunda mekanın özgün değerini } \\
\text { yitirmeyecek ekolojik, ekonomik ve estetik kriterler göz } \\
\text { önünde bulundurularak seçim yapılmalıdır. }\end{array}$ \\
\hline $\begin{array}{l}\text { KMR-9=Feyzullah } \\
\text { Paşa Cami }\end{array}$ & $\begin{array}{l}\text { Manevi yönden iç rahatlatma, caminin çevre } \\
\text { düzenlenmelerine ve katkıda bulunma. }\end{array}$ & $\begin{array}{l}\text { Caminin peyzaj tasarım projesi ortaya konulmalı ve } \\
\text { ziyaretçilerin alanda daha kontrollü vakit geçirebilmeleri için } \\
\text { mekânlar tasarlanmalıdır. }\end{array}$ \\
\hline $\begin{array}{l}\text { KMR-10=Ertokuş } \\
\text { Kümbeti }\end{array}$ & $\begin{array}{l}\text { Tarihi kültürel değerleri sahiplenme ve koruma } \\
\text { Medresenin gerek iç mimarisine gerekse } \\
\text { peyzaj tasarımına katkılar sunma, manevi bir } \\
\text { rahatlama, medreseye maddi anlamda destek } \\
\text { sağlama, tarihi kültürü benimseme. }\end{array}$ & $\begin{array}{l}\text { Alana gelen ziyaretçilere mekâna ilişkin bilgilendirme } \\
\text { yapılması adına gerekli bilgilendirme pano ve levhaları } \\
\text { tasarlanmalıdır, gerekirse tanıtım kulübesi yapılmalıdır. }\end{array}$ \\
\hline $\begin{array}{l}\text { KMR-11=Ertokuş } \\
\text { Medresesi }\end{array}$ & $\begin{array}{l}\text { Tarihi kültürel değerleri sahiplenme ve koruma } \\
\text { Medresenin gerek iç mimarisine gerekse } \\
\text { peyzaj tasarımına katkılar sunma, manevi bir } \\
\text { rahatlama, medreseye maddi anlamda destek } \\
\text { sağlama, tarihi kültürü benimseme. }\end{array}$ & $\begin{array}{l}\text { Medresenin peyzaj tasarım projesi ortaya konulmalı ve } \\
\text { ziyaretçilerin alanda daha rahat, kontrollü vakit geçirebilmeleri } \\
\text { için mekânlar tasarlanmalıdır. }\end{array}$ \\
\hline $\begin{array}{l}\text { KMR-12=Şeyh Veli } \\
\text { Efendi Türbesi }\end{array}$ & $\begin{array}{l}\text { Türbenin çevre düzenlemesine ve temizliğinin } \\
\text { yapılmasına katkıda bulunma, manevi yönden } \\
\text { iç rahatlatma. }\end{array}$ & $\begin{array}{l}\text { Mekânın çevre düzenlemesi yapılmalıdır ve mekânın } \\
\text { ziyaretçiler tarafından daha anlaşılır hale gelmesi için mekânla } \\
\text { ilgili bilgilendirme panoları tasarlanmalıdır. }\end{array}$ \\
\hline $\begin{array}{l}\text { KMR-13=Atabey } \\
\text { Çayırlı Mescit }\end{array}$ & $\begin{array}{l}\text { Piknik yapmak, manzara izlemek, dinlenmek, } \\
\text { çöp toplamak, alanın çevre düzenlemesine } \\
\text { katkıda bulunmak ve soft trekking } \\
\text { faaliyetlerine katılmak. }\end{array}$ & $\begin{array}{l}\text { Mekânın silüetine aykırı olmayan ve tarihi doku karakterini ve } \\
\text { ölçeğini bozmayacak nitelikte bir peyzaj tasarımının yapılması }\end{array}$ \\
\hline $\begin{array}{l}\text { KMR-14=Atabey At } \\
\text { Çiftliği }\end{array}$ & $\begin{array}{l}\text { Ata binme, at binme yarışmalarına katılma, } \\
\text { piknik yapma, dinlenme, meyve toplama, } \\
\text { yabani otları çapalama-yolma. }\end{array}$ & $\begin{array}{l}\text { Çiftliğin restore ve peyzaj tasarım projesi ortaya konulmalı ve } \\
\text { ziyaretçilerin alanda daha rahat, kontrollü vakit geçirebilmeleri } \\
\text { için mekânlar tasarlanmalıdır. }\end{array}$ \\
\hline
\end{tabular}


Atabey ilçesinde oluşturulan kısa mesafeli rota noktaları Şekil 2'de verilmiştir.

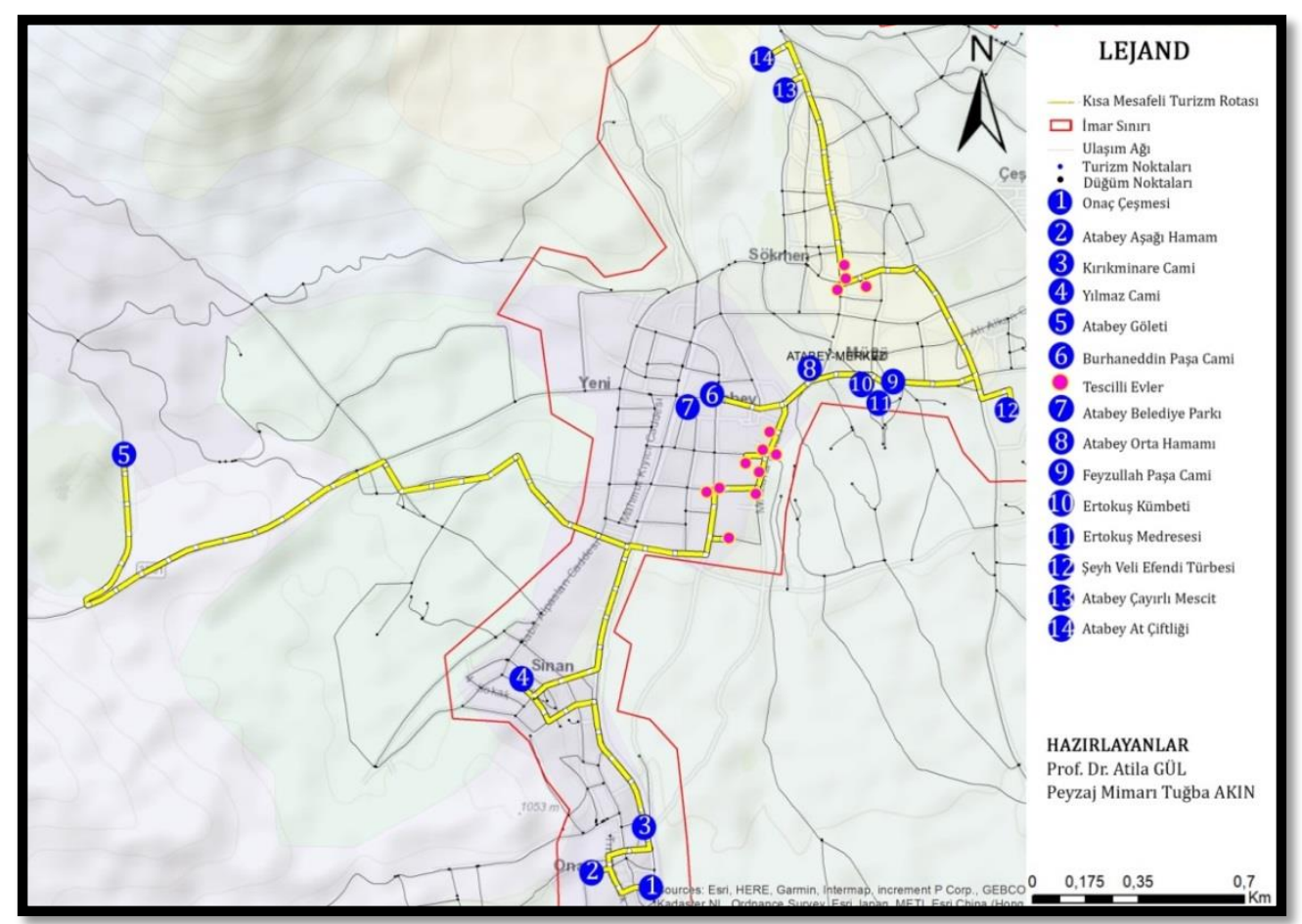

Şekil 2. Kısa mesafeli turizm rotası

Orta Mesafeli Rota (KMR): Atabey ilçesinde önerilmiş olan bu rota 22,97 km uzunluğunda olup rota üzerindeki turizm noktaları şu şekildedir; Sezgin Yılmaz Yağhanesi, Tarihi Değirmen, İslamköy Yeni Cami, Garaahmetler Haşhaş Yağhanesi, Koyun Dede Türbesi, İslamköy Orta Mescit Cami, Çiftçi Dede Türbesi, Okkalılar Yağhanesi, İzzet Ağa Türbesi, Delikli Taş Türbesi, Süleyman Demirel Devlet Anıtı, Çalca Dede Türbesi, Hüseyin Aykut Gül Yağhanesi, Tarihi Su Sarnıcı, İslamköy Şehriban Hatun Cami, İslamköy Hacı Kavas Çeşmesi, Hıdır Cami, Hıdır Cami Çeşmesi, İslamköy Park Çeşmesi, İslamköy Arapoğlu Cami, Alaaddin Öztürk Sabunhanesi, İslamköy Giriş Çeşmesi, Hatıpların Çeşmesi, Gökmen Dede Türbesi, Rüstem Paşa Cami, Rüstem Paşa Cami Çeşmesi, Tarihi Hamam, Gülbirlik, Tescilli Evler, Veli Efendi Türbesi, Feyzulllah Paşa Cami, Ertokuş Bey Medresesi, Ertokuş Külliyesi, Atabey Orta Hamamı, Burhanettin Paşa Cami, Atabey Belediye Parkı, Atabey Çayırlı Mescit, Atabey At Çiftliği, Yılmaz cami, Kırık Minare Cami, Aşağı Hamam, Onaç Çeşmesi, Sezgin Yılmaz Yağhanesi ve son olarak Atabey ilçesinde bulunan Tescilli Evler şeklindedir.

Öneri turizm rotası ve turizm noktaları Şekil 3'te ve ayrıca Şekil 4'te ve Şekil 5'te orta mesafeli turizm rotası detaylı bir şekilde gösterilmiştir. Oluşturulan öneri rotasıyla ilgili bilgiler (Rota noktaları, nokta üzerinde yapılacak etkinlikler ve mekânsal tasarım önerileri Çizelge 2' de gösterilmiştir.

Çizelge 2. Orta mesafeli rota noktaları, yapılacak etkinlikler ve mekânsal tasarım önerileri

\begin{tabular}{|c|c|c|}
\hline Rota Noktaları & Yapılacak Etkinlik & Mekânsal Öneriler \\
\hline $\begin{array}{l}\text { OMR-1= } \\
\text { Sezgin Yılmaz } \\
\text { Yağhanesi }\end{array}$ & $\begin{array}{l}\text { Yağ üretimi ve gül yetiştirilmesiyle bağlantılı farklı } \\
\text { halk gelenekleri hakkında bilgi edinimi, fotoğraf } \\
\text { çekinme, gül ile vücut terapi masajları ve maske } \\
\text { yaptırma ve yağ üretiminin yeniden } \\
\text { canlandırılmasına ve mekanın eski ruhunu } \\
\text { yeniden kazandırılmasına yönelik yapılan } \\
\text { çalışmalara katkılar sunma. }\end{array}$ & $\begin{array}{l}\text { Eskiden gül yağının çıkarıldığı bu mekânın eski ruhunu } \\
\text { yeniden canlandıracak şekilde mekanın yeniden } \\
\text { kurgulanması ve canlandırılması gerekmektedir, alanda } \\
\text { bulunan kalıntıların korunması ve sunumu arasındaki } \\
\text { dengeyi sağlayacak şekilde mekânsal tasarımın ön görülmesi } \\
\text { ve farklı sosyal, kültürel ve manevi ritüeller ve faaliyetlere } \\
\text { olanak sağlayacak mekanların kurgulanması. }\end{array}$ \\
\hline $\begin{array}{l}\text { OMR-2= } \\
\text { Tarihi Değirmen }\end{array}$ & $\begin{array}{l}\text { Değirmenin tarihi ile ilgili bilimsel araştırma } \\
\text { çalışmalarına katılma. }\end{array}$ & $\begin{array}{l}\text { Mekânın eski kullanımını canlandıracak şekilde kurgulanması } \\
\text { ve alanda bulunan kalıntıların korunması ve sunumu } \\
\text { arasındaki dengeyi sağlayacak şekilde mekânsal tasarımın ön } \\
\text { görülmesi ve farklı sosyal, kültürel ve manevi ritüeller ve } \\
\text { faaliyetlere olanak sağlayacak mekânların kurgulanması. }\end{array}$ \\
\hline OMR-3= & Manevi yönden iç rahatlatma, caminin çevre & Mekânın çevre düzenlemesi yapılmalıdır. \\
\hline
\end{tabular}




\begin{tabular}{|c|c|}
\hline $\begin{array}{l}\text { İslamköy Yeni } \\
\text { Cami }\end{array}$ & $\begin{array}{l}\text { düzenlenmelerine ve katkıda bulunma ve } \\
\text { fotoğraf çekinme. }\end{array}$ \\
\hline $\begin{array}{l}\text { OMR-4= } \\
\text { Garaahmetler } \\
\text { Haşhaş Yağhanesi }\end{array}$ & $\begin{array}{l}\text { Haşhaş yağı üretimi, haşhaş öğütme ve haşhaş } \\
\text { yetiştirilmesiyle bağlantılı farklı halk gelenekleri } \\
\text { hakkında bilgi edinimi, fotoğraf çekinme, } \\
\text { yağhanenin tarihi izi hakkında bilgi toplama ve } \\
\text { bilimsel çalışmalara katılma ve yağ üretiminin } \\
\text { yeniden canlandırılmasına ve mekânın eski } \\
\text { ruhunu yeniden kazandırılmasına yönelik yapılan } \\
\text { çalışmalara katkılar sunma. }\end{array}$ \\
\hline $\begin{array}{l}\text { OMR-5= } \\
\text { Koyun Dede } \\
\text { Türbesi }\end{array}$ & $\begin{array}{l}\text { Atabey ilçesine ait gelenek ve görenekleri } \\
\text { canlandırma, Manevi yönden iç rahatlatma, } \\
\text { türbenin çevre düzenlenmelerine ve katkıda } \\
\text { bulunma. }\end{array}$ \\
\hline $\begin{array}{l}\text { OMR-6= } \\
\text { İslamköy Orta } \\
\text { Mescit Cami }\end{array}$ & $\begin{array}{l}\text { Manevi yönden iç rahatlatma, caminin çevre } \\
\text { düzenlenmelerine ve katkıda bulunma ve } \\
\text { fotoğraf çekme. }\end{array}$ \\
\hline
\end{tabular}

Mekânın eski kullanımını canlandıracak şekilde kurgulanması ve alanda bulunan kalıntıların korunması ve sunumu arasındaki dengeyi sağlayacak şekilde mekânsal tasarımın ön görülmesi ve farklı sosyal, kültürel ve manevi ritüeller ve faaliyetlere olanak sağlayacak mekânların kurgulanması

Mekânın çevre düzenlemesi yapılmalıdır ve mekânın ziyaretçiler tarafından daha anlaşılır hale gelmesi için mekânla ilgili bilgilendirme panoları tasarlanmalıdır.

Caminin peyzaj tasarım projesi hazırlanmalı ve Mekânın içinde yer aldığı kırsal dokunun mimarî karakteri ve İslamköy'ün bütününde var olan diğer doğal, kültürel ve görsel değerler ile entegre edilerek mekânsal tasarımı kurgulanmalıdır.

\begin{tabular}{ll}
\hline $\begin{array}{l}\text { OMR-7= } \\
\text { Çiftçi } \\
\text { Türbesi }\end{array}$ & $\begin{array}{l}\text { Atabey ilçesine ait gelenek ve görenekleri } \\
\text { canlandırma, Manevi yönden iç rahatlatma, } \\
\text { türbenin çevre düzenlenmelerine ve katkıda } \\
\text { bulunma. }\end{array}$ \\
\hline OMR-8= & Yağ üretimi hakkında bilgi edinme, yağ üretiminin \\
Okkalılar & yeniden canlandırılmasına ve mekânın eski \\
Yağhanesi & ruhunu yeniden kazandırılmasına yönelik yapılan \\
& çalışmalara katkılar sunma.
\end{tabular}

OMR-9= Atabey ilçesine ait gelenek ve görenekleri

İzzet Ağa Türbesi canlandırma, Manevi yönden iç rahatlatma, türbenin çevre düzenlenmelerine ve katkıda bulunma.

OMR-10= Atabey ilçesine ait gelenek ve görenekleri

Delikli Taş Türbesi canlandırma, Manevi yönden iç rahatlatma, türbenin çevre düzenlenmelerine ve katkıda bulunma.

OMR-11= Manevi yönden iç rahatlatma, devlet anıtının

Süleyman Demirel çevre düzenlenmelerine ve katkıda bulunma.

Mekânın çevre düzenlemesi yapılmalıdır ve mekânın ziyaretçiler tarafından daha anlaşılır hale gelmesi için mekânla ilgili bilgilendirme panoları tasarlanmalıdır.

Mekânın eski kullanımını canlandıracak şekilde kurgulanması ve alanda bulunan kalıntıların korunması ve sunumu arasındaki dengeyi sağlayacak şekilde mekânsal tasarımın ön görülmesi ve farklı sosyal, kültürel ve manevi ritüeller ve faaliyetlere olanak sağlayacak mekânların kurgulanması

Mekânın çevre düzenlemesi yapılmalıdır ve mekânın ziyaretçiler tarafından daha anlaşılır hale gelmesi için mekânla ilgili bilgilendirme panoları tasarlanmalıdır.

Mekânın çevre düzenlemesi yapılmalıdır ve mekânın ziyaretçiler tarafından daha anlaşılır hale gelmesi için mekânla ilgili bilgilendirme panoları tasarlanmalıdır.

Kırsal kimliğin dışına çıkmayarak ve mekânı Süleyman Demirel ile ilişkilendirerek çevre düzenlemesi yapılmalıdır

Devlet Anıtı

\begin{tabular}{|c|c|}
\hline $\begin{array}{l}\text { OMR-12= } \\
\text { Çalca } \\
\text { Türbesi }\end{array}$ & $\begin{array}{l}\text { Atabey ilçesine ait gelenek ve görenekleri } \\
\text { canlandırma, Manevi yönden iç rahatlatma, } \\
\text { türbenin çevre düzenlenmelerine ve katkıda } \\
\text { bulunma. }\end{array}$ \\
\hline OMR-13= Hüseyin & Yağ üretimi ve gül yetiştirilmesiyle bağlantılı farklı \\
\hline $\begin{array}{ll}\text { Aykut } & \text { Gül } \\
\text { Yağhanesi } & \end{array}$ & $\begin{array}{l}\text { halk gelenekleri hakkında bilgi edinimi, fotoğraf } \\
\text { çekinme, gül ile vücut terapi masajları ve maske } \\
\text { yaptırma ve yağ üretiminin yeniden } \\
\text { canlandırılması. }\end{array}$ \\
\hline $\begin{array}{l}\text { OMR-14= } \\
\text { Tarihi Su Sarnıcı }\end{array}$ & $\begin{array}{l}\text { Sarnıçtan su çekme gibi geleneksel yaşamın } \\
\text { canlandırılması, fotoğraf çekinme. Sarnıcın tarihi } \\
\text { ile ilgili bilimsel çalışmalara destek olma ve } \\
\text { sarnıcın çevre düzenlemesine katkıda bulunma. }\end{array}$ \\
\hline
\end{tabular}

OMR-15= Manevi yönden iç rahatlatma, caminin çevre

İslamköy Şehriban düzenlenmelerine ve katkıda bulunma ve Hatun Cami fotoğraf çekinme.

\section{OMR-16=}

İslamköy $\mathrm{Hacı}$

Kavas Çeşmesi

OMR-17=

Hıdır Cami

Mekânın çevre düzenlemesi yapılmalıdır ve mekanın ziyaretçiler tarafından daha anlaşılır hale gelmesi için mekanla ilgili bilgilendirme panoları tasarlanmalıdır.

Mekânın eski kullanımını canlandıracak şekilde kurgulanması ve alanda bulunan kalıntıların korunması ve sunumu arasındaki dengeyi sağlayacak şekilde mekânsal tasarımın ön görülmesi ve ayrıca farklı sosyal, kültürel ve manevi ritüeller ve faaliyetlere olanak sağlayacak mekân kurgulanması

Mekânın eski kullanımını canlandıracak şekilde kurgulanması ve alanda bulunan kalıntıların korunması ve sunumu arasındaki dengeyi sağlayacak şekilde mekânsal tasarımın ön görülmesi

Caminin peyzaj tasarım projesi hazırlanmalı ve Mekanın içinde yer aldığı kırsal dokunun mimarî karakteri ve İslamköy'ün bütününde var olan diğer doğal, kültürel ve görsel değerler ile entegre edilerek mekânsal tasarımı kurgulanmalıdır.

Çeşmenin doğal yapısı dikkate alınarak korunmalı ve yöreye ait malzemeler kullanılarak çeşmenin onarılması ve projelendirilmesi gerekmektedir.

Caminin peyzaj tasarım projesi hazırlanmalı ve Mekanın içinde yer aldığı kırsal dokunun mimarî karakteri ve İslamköy'ün bütününde var olan diğer doğal, kültürel ve görsel değerler ile entegre edilerek mekânsal tasarımı kurgulanmalıdır.

\begin{tabular}{|c|c|c|}
\hline $\begin{array}{l}\text { OMR-18= } \\
\text { Hıdır Cami } \\
\text { Çeşmesi }\end{array}$ & $\begin{array}{l}\text { Çeşmenin tarihi ile ilgili bilimsel çalışmalara } \\
\text { destek olma ve sarnıcın çevre düzenlemesine } \\
\text { katkıda bulunma. }\end{array}$ & $\begin{array}{l}\text { Çeşmenin doğal yapısı dikkate alınarak korunmalı ve yöreye } \\
\text { ait malzemeler kullanılarak çeşmenin onarılması ve } \\
\text { projelendirilmesi gerekmektedir. }\end{array}$ \\
\hline $\begin{array}{l}\text { OMR-19= } \\
\text { İslamköy Park } \\
\text { Çeşmesi }\end{array}$ & $\begin{array}{l}\text { Çeşmenin tarihi ile ilgili bilimsel çalışmalara } \\
\text { destek olma ve sarnıcın çevre düzenlemesine } \\
\text { katkıda bulunma. }\end{array}$ & $\begin{array}{l}\text { Çeşmenin doğal yapısı dikkate alınarak korunmalı ve yöreye } \\
\text { ait malzemeler kullanılarak çeşmenin onarılması ve } \\
\text { projelendirilmesi gerekmektedir. }\end{array}$ \\
\hline
\end{tabular}




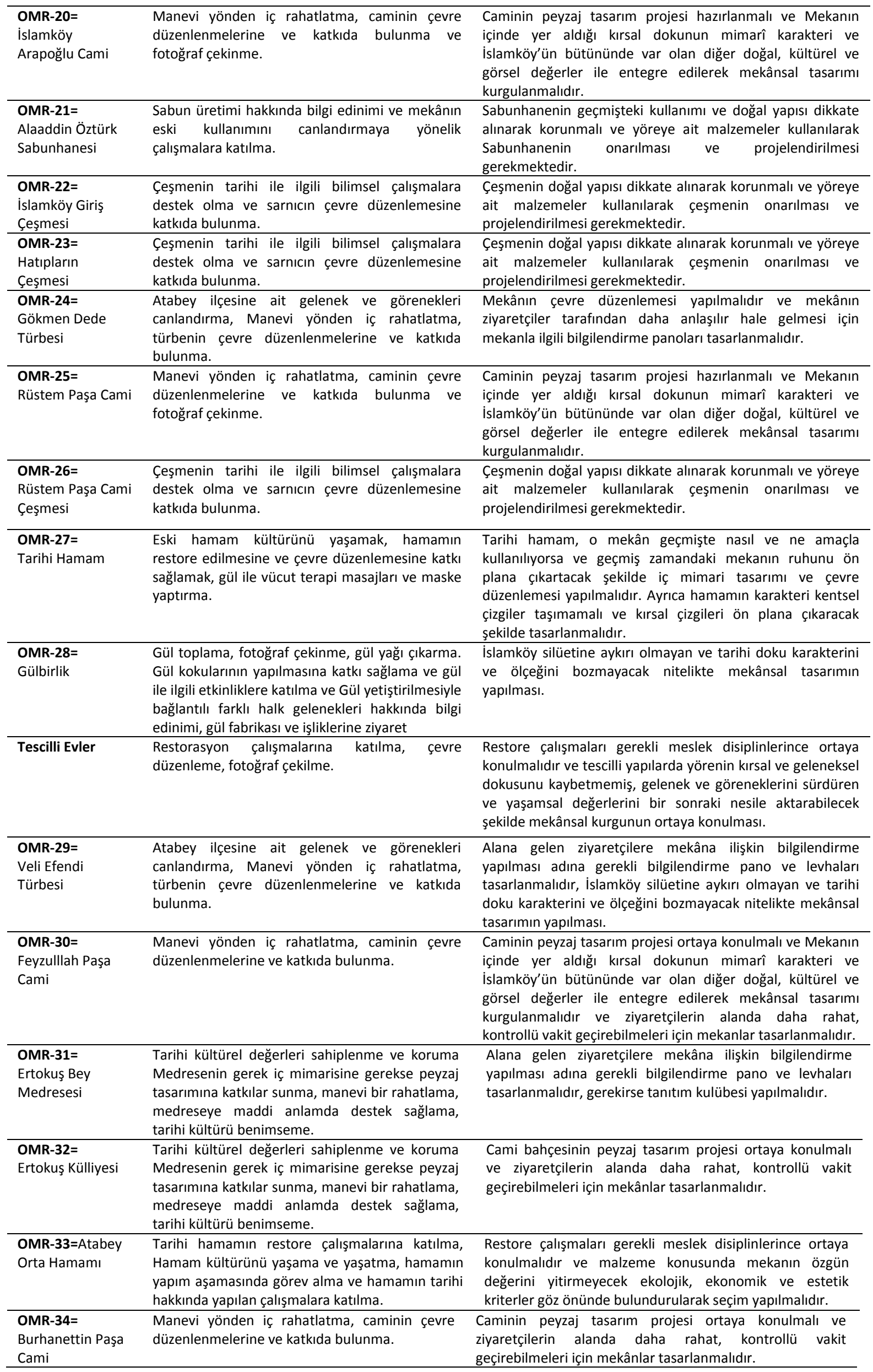




\begin{tabular}{|c|c|c|}
\hline $\begin{array}{l}\text { OMR-35= } \\
\text { Atabey Belediye } \\
\text { Parkı }\end{array}$ & $\begin{array}{l}\text { Piknik yapma, dinlenme, parkın çevre } \\
\text { düzenlenmelerine katkıda bulunma. }\end{array}$ & $\begin{array}{l}\text { Parkın restore ve peyzaj tasarım projesi ortaya konulmal } \\
\text { ve ziyaretçilerin alanda daha rahat, kontrollü vakit } \\
\text { geçirebilmeleri için mekânlar tasarlanmalıdır. }\end{array}$ \\
\hline $\begin{array}{l}\text { OMR-36= } \\
\text { Atabey Çayırlı } \\
\text { Mescit }\end{array}$ & $\begin{array}{l}\text { Piknik yapmak, manzara izlemek, dinlenmek, } \\
\text { çöp toplamak, alanın çevre düzenlemesine } \\
\text { katkıda bulunmak ve doğa ile baş başa kalmak } \\
\text { ve açık hava ve rekreasyon etkinliklerine } \\
\text { katılmak. }\end{array}$ & $\begin{array}{l}\text { Mekânın silüetine aykırı olmayan ve tarihi doku karakterin } \\
\text { ve ölçeğini bozmayacak nitelikte bir peyzaj tasarımının } \\
\text { yapılması }\end{array}$ \\
\hline $\begin{array}{l}\text { OMR-37= } \\
\text { Atabey At Çiftliği }\end{array}$ & $\begin{array}{l}\text { Ata binme, at binme yarışmalarına katılma, } \\
\text { piknik yapma, dinlenme, meyve toplama, yabani } \\
\text { otları çapalama-yolma. }\end{array}$ & $\begin{array}{l}\text { Çiftliğin restore ve peyzaj tasarım projesi ortaya konulmal } \\
\text { ve ziyaretçilerin alanda daha rahat, kontrollü vakit } \\
\text { geçirebilmeleri için mekânlar tasarlanmalıdır. Ayrıca } \\
\text { mekâna herkese hitap eden farklı rekreasyonel etkinliklerin } \\
\text { gerçekleştirilebileceği mekânların öngörülmesi }\end{array}$ \\
\hline $\begin{array}{l}\text { OMR-38= } \\
\text { Yılmaz cami }\end{array}$ & $\begin{array}{l}\text { Manevi yönden iç rahatlatma, caminin çevre } \\
\text { düzenlenmelerine ve katkıda bulunma. }\end{array}$ & $\begin{array}{l}\text { Caminin peyzaj tasarım projesi ortaya konulmalı ve } \\
\text { Mekanın içinde yer aldığı kırsal dokunun mimarî karakter } \\
\text { ve İslamköy'ün bütününde var olan diğer doğal, kültürel ve } \\
\text { görsel değerler ile entegre edilerek mekânsal tasarım } \\
\text { kurgulanmalıdır ve ziyaretçilerin alanda daha rahat, } \\
\text { kontrollü vakit geçirebilmeleri için mekanlar } \\
\text { tasarlanmalıdır. }\end{array}$ \\
\hline $\begin{array}{l}\text { OMR-39= } \\
\text { Kırık Minare Cami }\end{array}$ & $\begin{array}{l}\text { Manevi yönden iç rahatlatma, caminin çevre } \\
\text { düzenlenmelerine ve katkıda bulunma. }\end{array}$ & $\begin{array}{l}\text { Caminin peyzaj tasarım projesi ortaya konulmalı ve } \\
\text { Mekanın içinde yer aldığı kırsal dokunun mimarî karakter } \\
\text { ve İslamköy'ün bütününde var olan diğer doğal, kültürel ve } \\
\text { görsel değerler ile entegre edilerek mekânsal tasarım } \\
\text { kurgulanmalıdır ve ziyaretçilerin alanda daha rahat, } \\
\text { kontrollü vakit geçirebilmeleri için mekanlar } \\
\text { tasarlanmalıdır. }\end{array}$ \\
\hline $\begin{array}{l}\text { OMR-40= } \\
\text { Aşağı Hamam }\end{array}$ & $\begin{array}{l}\text { Hamam kültürünü yaşama, Tarihi hamamın } \\
\text { restore çalışmalarına katılma, hamamın restore } \\
\text { çalışmalarında görev alma ve hamamın tarihi } \\
\text { hakkında yapılan çalışmalara katılma. }\end{array}$ & $\begin{array}{l}\text { Restore çalışmaları gerekli meslek disiplinlerince ortaya } \\
\text { konulmalıdır ve malzeme konusunda mekanın özgün } \\
\text { değerini yitirmeyecek ekolojik, ekonomik ve estetik } \\
\text { kriterler göz önünde bulundurularak seçim yapılmalıdır. }\end{array}$ \\
\hline $\begin{array}{l}\text { OMR-41= } \\
\text { Onaç Çeşmesi }\end{array}$ & $\begin{array}{l}\text { Çeşmenin tarihi ile ilgili bilimsel çalışmalara } \\
\text { destek olma ve sarnıcın çevre düzenlemesine } \\
\text { katkıda bulunma. }\end{array}$ & $\begin{array}{l}\text { Çeşmenin doğal yapısı dikkate alınarak korunmalı ve yöreye } \\
\text { ait malzemeler kullanılarak çeşmenin onarılması ve } \\
\text { projelendirilmesi gerekmektedir. }\end{array}$ \\
\hline $\begin{array}{l}\text { OMR-42= } \\
\text { 3. Derece } \\
\text { Arkeolojik Sit } \\
\text { Alanı }\end{array}$ & $\begin{array}{l}\text { Fotoğraf çekinmek, alanın tarihi ile ilgili bilimsel } \\
\text { çalışmalara katılmak, alanın restore edilmesine } \\
\text { ve arkeolojik kazı çalışmalarına katkıda } \\
\text { bulunmak, Arkeolojik sit alanının sunumu ve } \\
\text { yorumlanmasına katkıda bulunmak. }\end{array}$ & $\begin{array}{l}\text { Mekânın ruhunu yansıtacak bir peyzaj tasarımı yapılmalıdır } \\
\text { ve Gelen ziyaretçileri bilgilendirmek ve yönlendirmek adına } \\
\text { okunabilirlik kalitesi yüksek olan donatı elemanlar } \\
\text { kullanılmalıdır. }\end{array}$ \\
\hline Tescilli Evler & $\begin{array}{l}\text { Tescilli evlerin tarihteki kullanımlarına yönelik } \\
\text { bilgi toplama, eski kullanımını yeniden } \\
\text { canlandırma, fotoğraf çekinme. }\end{array}$ & $\begin{array}{l}\text { Doğa dostu üretim ve tüketim modellerinin sunulduğu } \\
\text { mekânların tasarlanması. }\end{array}$ \\
\hline
\end{tabular}

Atabey ilçesinde oluşturulan orta mesafeli turizm rotasının genel görünümü Şekil 3'te gösterilmiştir.

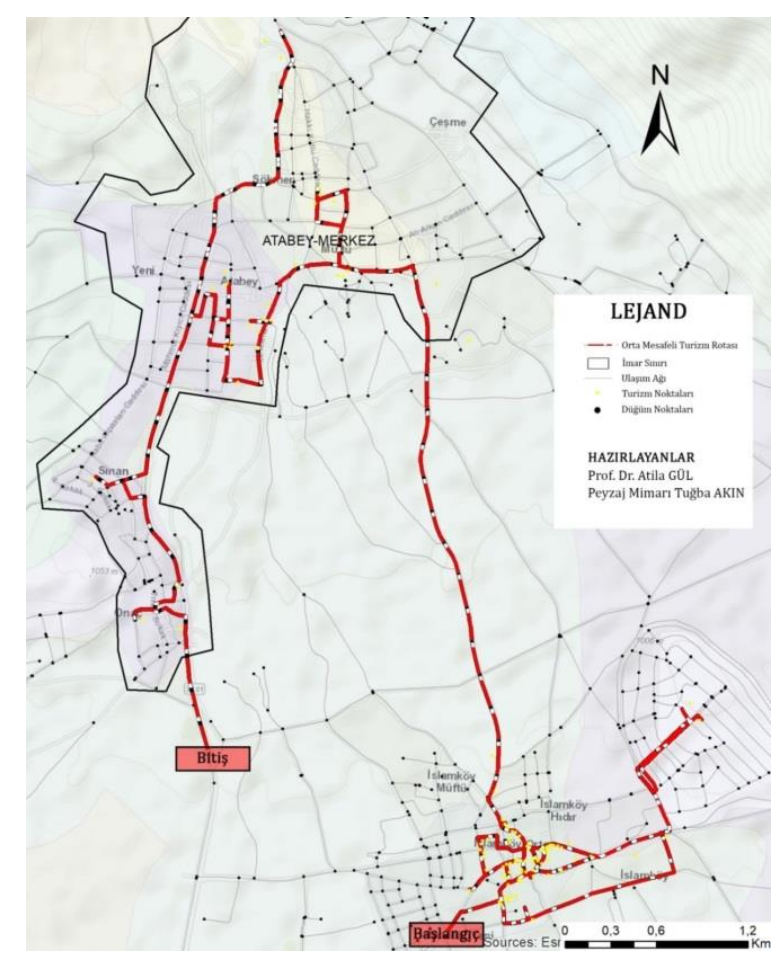

Şekil3. Orta mesafeli turizm rotası (Tamamı) 


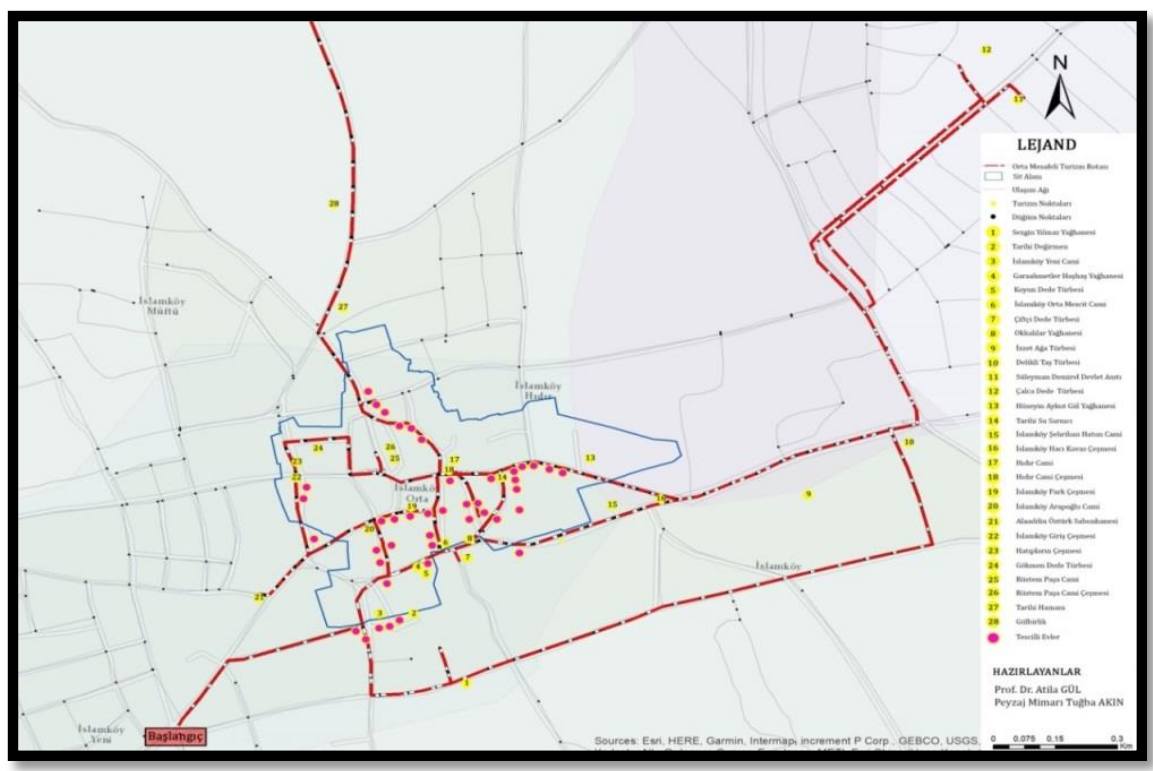

Şekil 4. Orta mesafeli turizm rotası (Başlangıç)

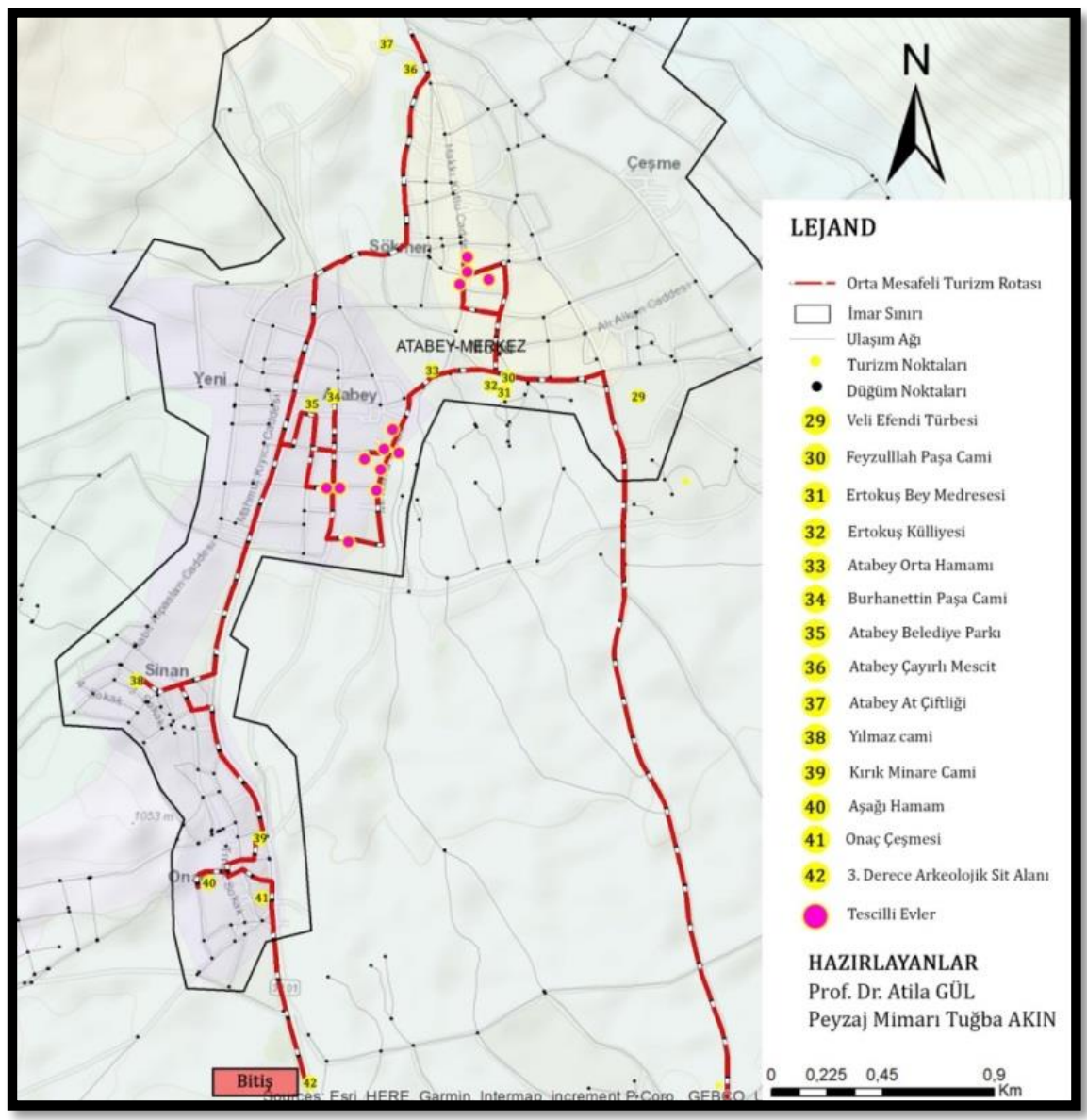

Şeki 5. Orta mesafeli turizm rotası(Bitiş)

UMR (Uzun mesafeli rota 1-3 gün): Atabey ilçesinde önerilmiş olan bu rota 41,95 km uzunluğunda olup, yürüyüş etkinliği ile 8 saatten fazla sürecek bir rotadır. Rota üzerindeki noktalar şu şekildedir; Bayat Köyü, Koca Tepecik Mevki Yerleşim Alanı, Seleukeia Sidera Antik Kenti, Sırçalı Netropolü, Antik Su Yolu, Göndürle Höyük, Harmanören Köyü, Pembeli Köyü, Odalarüstü Mevki Kaya mezarı, Balıklı çeşme kalesi, Yassıardıç kale kalıntısı, Pamuklu höyük, Atabey Merkez ve son olarak i̇slamköy merkeze ulaşmaktadır (Şekil 6). 


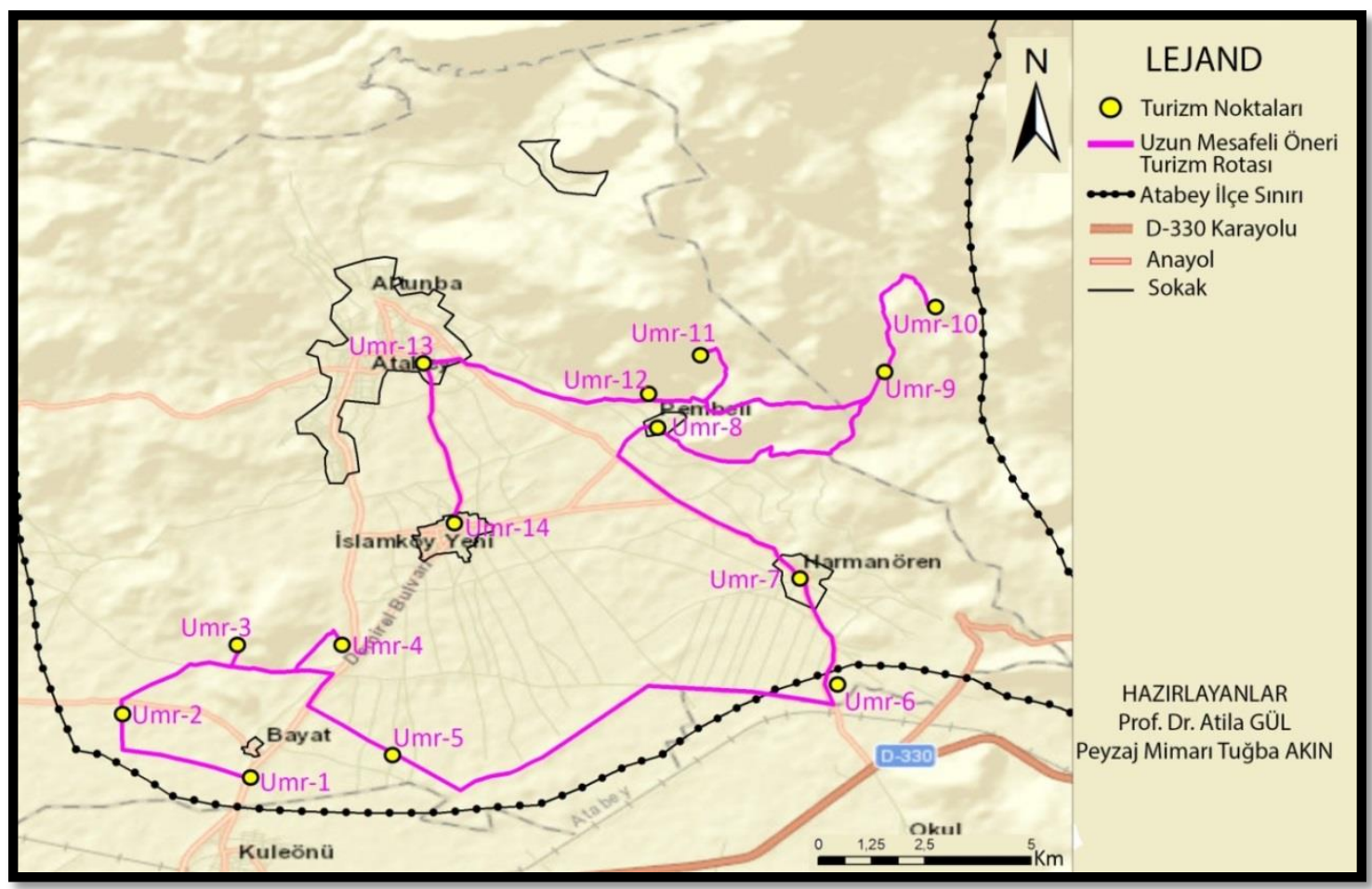

Şekil 6. Atabey ilçesi uzun mesafeli turizm rotası

Oluşturulan öneri rotasıyla ilgili bilgiler Rota noktaları, nokta üzerinde yapılacak etkinlikler ve mekânsal tasarım önerileri Çizelge 4'te gösterilmiştir.

Çizelge 4. Uzun mesafeli rota noktaları, yapılacak etkinlikler ve mekânsal tasarım önerileri

\begin{tabular}{|c|c|c|}
\hline Rota Noktaları & Yapılacak Etkinlik & Mekânsal Öneriler \\
\hline $\begin{array}{l}\text { UMR-1=Bayat } \\
\text { Köyü }\end{array}$ & $\begin{array}{l}\text { Köy kültürünü yaşama, köy halkının işlerine } \\
\text { yardım etme(Meyve toplama, inek sağma, } \\
\text { keçi otlatma vb.), bir köy ziyareti ve yöre } \\
\text { haklıyla etkileşim kurarak aynı yaşamı } \\
\text { paylaşmak, köy düğünlerine katılmak, } \\
\text { geleneksel köy yemeklerini pişirmek. }\end{array}$ & $\begin{array}{l}\text { Köy içi sokak ve kaldırımların köye özgü malzemeler } \\
\text { kullanılarak tasarımının yapılması ve köy girişine bilgilendirme } \\
\text { ve 'hoşgeldiniz' tabelası koyulmalıdır. }\end{array}$ \\
\hline $\begin{array}{l}\text { UMR-2=Koca } \\
\text { Tepecik Mevki } \\
\text { Yerleşim Alanı }\end{array}$ & $\begin{array}{l}\text { Erozyon kontrol çalışmaları, kazı çalışmaları, } \\
\text { Öğrenme ve keşfetme faaliyetleri, Tarihi ve } \\
\text { antik geziler. }\end{array}$ & $\begin{array}{l}\text { Arkeolojik mekânların tasarımı kapsamında } \\
\text { kurgulanması. }\end{array}$ \\
\hline $\begin{array}{l}\text { UMR-3=Seleukeia } \\
\text { Sidera Antik Kenti }\end{array}$ & $\begin{array}{l}\text { Fotoğraf çekimi, Manzara seyretme, Bitki } \\
\text { gözlemi ve inceleme faaliyetleri, Bitki } \\
\text { budama, bakım ve ilaçlama vb. faaliyetleri, } \\
\text { Doğa koruma farkındalık faaliyetleri, Tarihi } \\
\text { ve antik geziler. }\end{array}$ & $\begin{array}{l}\text { Arkeolojik mekânların tasarımı kapsamında } \\
\text { kurgulanması. }\end{array}$ \\
\hline $\begin{array}{l}\text { UMR-4=Sırçalı } \\
\text { Netropolü }\end{array}$ & $\begin{array}{l}\text { Doğa koruma farkındalık faaliyetleri, Tarihi } \\
\text { ve antik geziler, kazı çalışmaları. }\end{array}$ & $\begin{array}{l}\text { Arkeolojik mekânların tasarımı kapsamında } \\
\text { kurgulanması. }\end{array}$ \\
\hline $\begin{array}{l}\text { UMR-5= Antik Su } \\
\text { Yolu }\end{array}$ & $\begin{array}{l}\text { Doğa koruma farkındalık faaliyetleri, Tarihi } \\
\text { ve antik geziler, kazı çalışmaları }\end{array}$ & $\begin{array}{llll}\begin{array}{l}\text { Arkeolojik mekânların tasarımı kapsamında } \\
\text { kurgulanması. }\end{array} & & \\
\end{array}$ \\
\hline $\begin{array}{l}\text { UMR-6= Göndürle } \\
\text { Höyük }\end{array}$ & $\begin{array}{l}\text { Doğa koruma farkındalık faaliyetleri, Tarihi } \\
\text { ve antik geziler, kazı çalışmaları. }\end{array}$ & $\begin{array}{l}\text { Arkeolojik mekânların tasarımı kapsamında } \\
\text { kurgulanması. }\end{array}$ \\
\hline $\begin{array}{l}\text { UMR-7= } \\
\text { Harmanören Köyü }\end{array}$ & $\begin{array}{l}\text { Köy kültürünü yaşama, köy halkının işlerine } \\
\text { yardım etme(Meyve toplama, inek sağma, } \\
\text { keçi otlatma vb.), bir köy ziyareti ve yöre } \\
\text { haklıyla etkileşim kurarak aynı yaşamı } \\
\text { paylaşmak, köy düğünlerine katılmak, } \\
\text { geleneksel köy yemeklerini pişirmek. }\end{array}$ & $\begin{array}{l}\text { Kırsal tasarım rehberi kapsamında mekânsal köy kurgusunun } \\
\text { yapılması. }\end{array}$ \\
\hline $\begin{array}{l}\text { UMR-8= Pembeli } \\
\text { Köyü }\end{array}$ & $\begin{array}{l}\text { Köy kültürünü yaşama, köy halkının işlerine } \\
\text { yardım etme(Meyve toplama, inek sağma, } \\
\text { keçi otlatma vb.), Yöresel bir köy ziyareti ve } \\
\text { yöre haklıyla etkileşim kurarak aynı yaşamı } \\
\text { paylaşmak, köy düğünlerine katılmak, } \\
\text { geleneksel köy yemeklerini pişirmek. }\end{array}$ & $\begin{array}{l}\text { Kırsal tasarım rehberi kapsamında mekânsal köy kurgusunun } \\
\text { yapılması. }\end{array}$ \\
\hline UMR-9= & Doğa koruma farkındalık faaliyetleri, Tarihi & kapsamında \\
\hline
\end{tabular}




\begin{tabular}{|c|c|c|}
\hline $\begin{array}{l}\text { Odalarüstü Mevki } \\
\text { Kaya mezarı }\end{array}$ & ve antik geziler, kazı çalışmaları. & kurgulanması. \\
\hline $\begin{array}{l}\text { UMR-10= Balıklı } \\
\text { çeşme kalesi }\end{array}$ & $\begin{array}{l}\text { Doğa koruma farkındalık faaliyetleri, Tarihi } \\
\text { ve antik geziler, kazı çalışmaları. }\end{array}$ & $\begin{array}{llll}\begin{array}{l}\text { Arkeolojik mekânların } \\
\text { kurgulanması. }\end{array} & \text { tasarımı kapsamında } & \text { alanın } \\
\end{array}$ \\
\hline $\begin{array}{l}\text { UMR-11= } \\
\text { Yassıardıç kale } \\
\text { kalıntısı }\end{array}$ & $\begin{array}{l}\text { Doğa koruma farkındalık faaliyetleri, Tarihi } \\
\text { ve antik geziler, kazı çalışmaları. }\end{array}$ & $\begin{array}{l}\text { Arkeolojik mekânların tasarımı kapsamında alanın } \\
\text { kurgulanması. }\end{array}$ \\
\hline $\begin{array}{l}\text { UMR-12=Pamuklu } \\
\text { höyük }\end{array}$ & $\begin{array}{l}\text { Doğa koruma farkındalık faaliyetleri, Tarihi } \\
\text { ve antik geziler, kazı çalışmaları. }\end{array}$ & $\begin{array}{llll}\begin{array}{l}\text { Arkeolojik mekânların tasarımı kapsamında } \\
\text { kurgulanması. }\end{array} & \\
\end{array}$ \\
\hline $\begin{array}{l}\text { UMR-13=Atabey } \\
\text { Merkez }\end{array}$ & $\begin{array}{l}\text { Merkezde bulunan doğal ve kültürel turizm } \\
\text { değerini gezme. }\end{array}$ & \\
\hline $\begin{array}{l}\text { UMR-14=islamköy } \\
\text { merkez }\end{array}$ & $\begin{array}{l}\text { Köy kültürünü yaşama, köy halkının işlerine } \\
\text { yardım etme(Meyve toplama, inek sağma, } \\
\text { keçi otlatma vb.), bir köy ziyareti ve yöre } \\
\text { haklıyla etkileşim kurarak aynı yaşamı } \\
\text { paylaşmak, köy düğünlerine katılmak, } \\
\text { geleneksel köy yemeklerini pişirmek. }\end{array}$ & $\begin{array}{l}\text { Kırsal tasarım rehberi kapsamında mekânsal köy kurgusunun } \\
\text { yapılması. }\end{array}$ \\
\hline
\end{tabular}

\section{Sonuç ve Öneriler}

Bu çalışmada doğal ve kültürel peyzaj değerlerine sahip olduğu bilinen Atabey ilıçesi ve çevre köylerin doğal ve kültürel ekoturizm için önemlilik taşıyan peyzaj değerleri ortaya konulmuş ve doğa odaklı, sürdürülebilir ekoturizm potansiyeli açısından değerlendirilmiştir. Bu turizm değerleri dikkate alınarak turizm rotası önerilmiştir. Atabey ilçesinin sahip olduğu ekoturizm değerlerini bu önerilen turizm rotaları sayesinde tek bir noktaya gidilmesinden ziyade illçenin sahip olduğu tüm turizm noktalarının bütünsel algılanması sağlanmıştır. Her bir turizm noktası üzerinde öngörülen çeşitli ekoturizm faaliyetleri unutulmaya yüz tutmuş kültürel değerlerin ve özgün değerlerin canlandırılmasını ve tanıtımının yapılmasına katkılar sunmuştur. Turizm rotalarında yapılacak eylem planları ile alansal, noktasal ve rotasal boyutta ekoturizm faaliyetleri ve eylemler öngörülmüştür ve öngörülen her bir turizm rotasında detaylı araştırmalar, peyzaj ve yapı ölçeğinde mekânsal düzenlemeler, bakım ve onarım çalışmaları hakkında öneriler sunulmuştur. Ayrıca rotalarda ziyaretçilere yönelik farklı ve çeşitli seçenekler oluşturulmuştur.

Atabey ilçesinde gelecek kuşaklara aktarılabilen doğa odaklı, korumacı sürdürülebilir ekoturizmin geliştirilmesi için genel öneriler şu şekilde sıralanabilir;

- Öncelikle Atabey illçe merkezi ve köylerinde bulunan doğal ve kültürel ekoturizm değerleri birbiriyle entegre edilmek koşuluyla geliştirilmeli, ulusal ve uluslararası boyutta tanınabilirliğinin sağlanması gerekmektedir.

- Antik dönemde önemli yeri olan çalışma alanında kazı çalışmalarının yapılması, yerli ve yabancı turistlere sunulması gerekmektedir.

- İlgili meslek disiplinlerince çalışma alanın koruma ve kullanma dengesi göz önünde bulundurularak bütüncül ekoturizm planlaması sağlanmalıdır.

- Alana özgü yerel kimlik değerlerini ön plana çıkaracak çalışmaların yapılması gerekmektedir.

- Doğal ve kültürel ekoturizm değerlerinin bütüncül bir şekilde korunması, yaşatılması, yorumlanması ve sunulmasını sağlamak adına gerekli çalışmaların yapılması önerilmelidir.

- Atabey ilçesinde ekoturizm etkinlikleri kapsamında hizmet sektörüne yeni yatırım alanları yaratıp, yerel kalkınmayı desteklemek gerekmektedir.

Atabey illçesinde mevcutta 11 tane doğa yürüyüşü temalı rota bulunmaktadır. Mevcuttaki doğa yürüyüşü temalı rotalar sadece sanal ortamda belirli noktaların birleştirildiği bir güzergâh şeklinde olup herhangi bir işlevsel özelliği bulunmayıp çevresinde bulunan turizm noktaları ile herhangi bir ilişki kurulmamıştır. Atabey İlçesine gelen ziyaretçiler için herhangi bir rehber ve yönlendirme niteliği taşımamaktadır.

Bu çalışmada önerilen kısa, orta ve uzun mesafeli turizm rotalar, mevcuttaki yürüyüş rotaları ile ilişkilendirmek suretiyle her bir turizm noktası çevresindeki turizm noktaları ile bütüncül olarak ilişkilendirilip, her bir nokta üzerinde doğa tabanlı turizm faaliyetleri ve mekânsal tasarım öneriler getirilmiştir. Bu rotalar Atabey ilç̧esine gelecek olan turistler ve yöre halkı için bir rehber niteliği 
taşıyabilecektir. Atabey ilçesinde oluşturulmuş kısa, orta ve uzun mesafeli rotaların sağladığı faydalar ve bu rotalar ile ilgili genel öneriler şu şekilde sıralanabilir;

- İlçede tüm turizm faaliyetleri ve organizasyonundan sorumlu İlçe Turizm Komisyonu oluşturulmalıdır.

- Öneri turizm rotaları sayesinde, Atabey ilcçesinde ve çevresinde yer alan önemli turistik kaynakların geliştirilebilecek, ulusal ve uluslararası tanınabilirliği sağlanabilecektir.

- Turizm rotaları; turizm yönünden az gelişmiş Atabey İlçesinin için önemli bir ekonomik gelişim aracı olabilecektir.

- Atabey îlçesine ait yere turizm rotaları için mekânsal ve kullanım standartlar tanımlanmalı ve illçe genelinde oluşturulan turizm rotaları için uygulanmalıdır.

- Her bir rota için peyzaj tasarım uygulama projeleri (1/500 veya $1 / 200$ veya 1 /100 ölçekte) yapılmalıdır.

- Iilçe ölçeğinde turizm rotaları için Ziyaretçi Yönetim programı oluşturulmalıdır.

- Her bir turizm rotasının zorluk derecesi belirlenmeli, işaretleme sistemlerinin rota bütününde ortak bir dil ile uygulanması, acenteler ve rehberler için tanıtım koşulları belirlenmelidir.

- Ziyaretçilerin turizm rotaları üzerinde güvenliği için; GPS takibi, riskli alanlarda oluşabilecek herhangi bir tehlikeye karşı doğal çevre ile uyumlu yürüyüş platformları, tırmanmayı kolaylaştırıcı çözümler, patika yolların düzenlemesi gibi pratik çözümler üretilmelidir (Çekül, 2015).

- Kontrollü kullanım faktörü göz önünde bulundurularak etkin ve sürdürülebilir bir ziyaretçi yönetimi geliştirilmelidir.

Son olarak Atabey illçesi ekoturizm amaçılı kullanılabilecek birçok doğal ve kültürel özelliklere sahiptir. $\mathrm{Bu}$ özelliklerin değerlendirilmesi kapsamında yapılacak her türlü çalışmalar yerel halkın geçim kaynaklarının geliştirilmesine ve çeşitlenmesine katkıda bulunacak, ulusal ve uluslararası tanınmasına ve ziyaretçi sayısının artmasına yol açabilecektir. Bu girişimler ekoturizm hakkında yerel halkın farkındalığını arttıracak ve ekoturizm ile ilgili bilinçlenmesine katkılar sunacaktır. Kültürel miras özelliği taşıyan Atabey ilıçesindeki doğal ve kültürel değerler yerli ve yabancı turistlerin çekim noktası haline gelebilecek ve aynı zamanda Isparta kültür turizmine önemli katkılar sağlayabilecektir.

\section{Teşekkür ve Bilgi Notu}

Bu makale, Süleyman Demirel Üniversitesi F.B.E. Peyzaj Mimarlığı Ana Bilim Dalı’nda tamamlanan Yüksek Lisans tezinden üretilmiştir ve FYL-2019-7366 no'lu proje kapsamında Süleyman Demirel Üniversitesi Bilimsel Araştırma Projeleri Koordinasyon Birimi (BAP) tarafından desteklenmiş olup desteklerinden dolayı SDÜ BAP'a teşekkür ederiz. Makalede, ulusal ve uluslararası araştırma ve yayın etiğine uyulmuştur. Çalışmada Etik Kurul izni gerekmemiştir.

\section{Kaynaklar}

Akın, A. (2016). Ekoturizm alanlarının değerlendirilmesi ve ekoturizmin uygulanabilirliğinin araştırılması (Gaziantep Örneği). Uluslararası Sosyal ve Ekonomik Bilimler Dergisi, Sayı: (2), 2531. Erişim bilgisi: http://ijses.org/index.php/ijses/article/view/189/195

Akpınar, E. ve Bulut, Y. (2010). Ülkemizde alternatif turizm bir dalı olan ekoturizmı çeşitlerinin bölgelere göre dağılımı ve uygulama alanları. III. Ulusal Karadeniz Ormancılık Kongresi, (IV), Artvin.

Aksan, Ş. ve Mert , A. (2016). Isparta Atabey Ovası'nın kuş türleri ve bollukları. Türkiye Ormancılık Dergisi, Sayı: 17(2), 153-157. Erişim bilgisi: https://doi.org/10.18182/tjf.61184

Arslan, Y. (2005). Erdek ve çevresinin ekoturizm açısından değerlendirilmesi. Balıkesir Üniversitesi Sosyal Bilimler Enstitüsü Dergisi, 8 (13), 29-53. Retrieved from https://dergipark.org.tr/tr/pub/baunsobed/issue/50339/651845

Atabey Belediyesi. (2020). Atabey İlçesi tarihi. Erişim Tarihi ve Adresi: (10.5.2020), https://www.atabey.bel.tr/ilcemiz-tarihcesi.html. 
Atabey Nüfusu. (2020, 12 09). Isparta Atabey Nüfus verileri Erişim Adresi (12.10.2020): https://www.nufusu.com/ilce/atabey_isparta-nufusu.

Barrena, E., Laporte, G., Ortega, F.A. ve Pozo, M.A. (2016). Planning Ecotourism Routes in Nature Parks. s.190.

Baykal, F. (2015). Uluslararası turizm ulaştırmasının akış yönü ve dağılış dokusu. Ege Coğrafya Dergisi, Sayı: 24(2), 57-68, İzmir.

Baytok A., Pelit E. ve Soybalı H. H. (2017). Alternatif turizm mi? turizmde çeşitlilik mi? kavramsal bir değerlendirme. Erzincan Üniversitesi Sosyal Bilimler Enstitüsü Dergisi (ERZSOSDE), Sayı:IV: 1-14.

Çekül. (2014). Çukurova Kültürel Rota Sistemi Mekansal Planlama Rehberi. ÇEKÜL Vakfı.

Çekül. (2015). Kültür Rotaları Planlama Rehberi. Tarihi Kentler Birliği Yayınları Kılavuz Kitapçıklar Dizisi 3, İstanbul.

Çevre Bilinci Platformu. (2020, 21 02). Erişim bilgisi: http://www.cevrebilinci.com/cevreci-tatilekoturizm-nedir/

Demir, C., Çevirgen, A. (2006). Turizm ve Çevre Yönetimi Sürdürülebilir Gelişme Yaklaşımı. Nobel Yayın Dağıtım, s.86, Ankara.

Demirci, D. (2014). Isparta'daki kervan yolları üzerine bazı düşünceler. Tarih Kültür ve Sanat Araştırmaları Dergisi. Cilt 3, Sayı 3 (2014) 98-123.

Denk, E. (2019). Genel Turizm Ders notları. 2018-2019 Atatürk Üniversitesi, Erzurum.

Türkiye'nin Gezi Rehberi. (2020, 04 06). Doğal güzelliklerimiz. Erişim bilgisi: (04.06.2020),https://dogalguzelliklerimiz.wordpress.com/isparta-tarihi-yapitlar/

Drumm, A., Moore, A. (2002). Ecotourism Development, An Introduction Ecotourism Planning. Vol. I. The Nature Conservancy, USA.

Eken, G., Bozdoğan, M., İsafendiyaroğlu, S., Kılıç, D. T., Lisa, Y. (2006). Türkiye'nin Önemli Doğa Alanları. Doğa Derneği Ankara. (1) 1,79.

Erdoğan, N. (2014). Ekoturizm Turizm, Çevre ve Sürdürülebilirlik. Sosyal Çevre Bilimleri, s.143-185. Siyasal Kitabevi.

Gül, A. ve Özaltın O. (2007).Türkiye'deki korunan doğal alanlarda ekoturizm amaçlı ekolojik planlama yaklaşımı. Ekolojik Mimarlık ve Planlama Ulusal Sempozyumu. Antalya Mimarlar Odası, 194203, Antalya.

Gül, A. ve Özaltın, O. (2008). Ekoturizm ve Isparta II. Gülçevrem Dergisi, Isparta II Çevre ve Orman Müdürlüğü. Sayı:3 18-21s. Isparta.

Gül, A., Akın T. ve Pekgöz, M. (2019). Ekoturizm etkinlikleri rotası eylem planı yaklaşımı; Isparta İslamköy örneği. VIII. National IV. International Eastern Mediterranean Tourism Symposium (IV. Uluslararası Doğu Akdeniz Turizm Sempozyumu). Mersin Üniversitesi, Anamur, -Türkiye.

Isparta il Kültür ve Turizm Müdürlüğü. (2020, 04 01). Ören Yerleri. Erişim bilgisi: https://isparta.ktb.gov.tr/TR-70971/oren-yerleri.html

Isparta Valiliği. (2020, 04 06). Atabey Illçesi. Erişim bilgisi: http://www.isparta.gov.tr/atabey

IUCN, (2015). The IUCN Red List of Threatened Species. Version 2015-4. Erişim Tarihi:26.06.2020. http://www.iucnredlist.org/search

Kentsel Strateji. (2020, 04 03t). Eko vizyon 1 Bakacak- Gölyaka- Abant Yeşil üçgeni için Eko-turizme dayalı kalkınma stratejisi. Erişim bilgisi: https://www.kentselstrateji.com/wpcontent/uploads/V-19_Duzce-Yesil-Ucgen.pdf

Kurdoğlu, O., Cırık, Ö., Lise, Y., Çağlayan, E., Akkurt, M., Kandemir S. ve Welch, G. (2006). Ayder Ekoturizm Planı. Doğa Derneği, Ankara. 
Lourens, M. (2007). Route tourism: a roadmap for successful destinations and local economic development. Development Southern Africa Dergisi, Sayı: 3(24), 475-490. Erişim bilgisi: https://doi.org/10.1080/03768350701445574

Meyer, D. (2004). Tourısm Routes And Gateways: Key İssues For The Development Of Tourism Routes And Gateways And Their Potential For Pro-Poor Tourism. Yurtdışı Kalkınma Enstitüsü. Erişim bilgisi: https://www.researchgate.net/publication/242371864

Parladır Karcl, A. ve Uçar, Y. (2018). Uzaktan Algılama Ve Coğrafi Bilgi Sistemlerinin Sulama Şebekelerinin Performans Değerlendirmesinde Kullanılması: Atabey Sulama Şebekesi Örneği. (Yüksek lisans tezi) Süleyman Demirel Üniversitesi, Fen Bilimleri Enstitüsü, Isparta.

Rahemtulla, Y.G. ve Wellstead, A.M. (2001). Ecotourism: Understanding Competing Expert and Academic Definitions. Infor. Report NorX-380 Canada.

Selim, S. ve Sönmez, N.K. (2017). Coğrafi bilgi sistemleri tabanlı rota planlama: Likya Bölgesi Idebessos Antik Kenti. Türkiye Ormancılık Dergisi, Sayı:18(4): 302-308.

Silbergh, D., Fladmark, M., Henry, G. ve Young, M. (1994). A strategy for theme trails. J. M. Fladmark (ed.), Cultural Tourism. London, Donhead.

The International Ecotourism Society. (2020, 11 02). Erişim bilgisi: https://ecotourism.org/what-isecotourism/

Peyzaj Mimarları Odası (PMO). (2020, 12 01). TMMOB. Erişim bilgisi: (12.01.2020) http://peyzajmimoda.org.tr/genel/bizden_detay.php?kod =999\&tipi=10006\&sube=0

Türker, N. (2013). Batı Karadeniz Bölümü Ekoturizm Kaynaklarının Değerlendirilmesi ve Bir Ekoturizm Rotası Önerisi. Uluslararası Sosyal Bilimler Dergisi, Sayı: 6 (4).

UNWTO. (2014). Thematic discussion: The Role of Tourism Routes in Fostering Regional Development and Integration. CE,98(5), Madrid.

Ünal Ankaya, F., Yazıcı, K., Balık, G. ve Aslan, B.G. (2018). Dünyada ve Türkiye'de Ekoturizm, SosyalKültürel ve Ekonomik Katkıları. Ulusal Çevre Bilimleri Araştırma Dergisi, Sayı 1(2): 69-72.

Wikiloc, (2020, 21 01). Dünyanın rotaları. Erişim bilgisi: https://tr.wikiloc.com/rotalari/geziyuruyus/turkiye/isparta/atabey. 